\title{
Comparison of Observed and Predicted Abutment Scour at Selected Bridges in Maine
}

By Pamela J. Lombard and Glenn A. Hodgkins

Prepared in cooperation with the

Maine Department of Transportation

Scientific Investigations Report 2008-5099 


\title{
U.S. Department of the Interior DIRK KEMPTHORNE, Secretary
}

\author{
U.S. Geological Survey \\ Mark D. Myers, Director
}

U.S. Geological Survey, Reston, Virginia: 2008

For more information on the USGS — the Federal source for science about the Earth, its natural and living resources, natural hazards, and the environment:

World Wide Web: http://www.usgs.gov

Telephone: 1-888-ASK-USGS

Any use of trade, product, or firm names is for descriptive purposes only and does not imply endorsement by the U.S. Government.

Although this report is in the public domain, permission must be secured from the individual copyright owners to reproduce any copyrighted materials contained within this report.

Suggested citation:

Lombard, P.J., and Hodgkins, G.A., 2008, Comparison of observed and predicted abutment scour at selected bridges in Maine: U.S. Geological Survey Scientific Investigations Report 2008-5099, 23 p., available only online at http://pubs.usgs.gov/sir/2008/5099. 


\section{Contents}

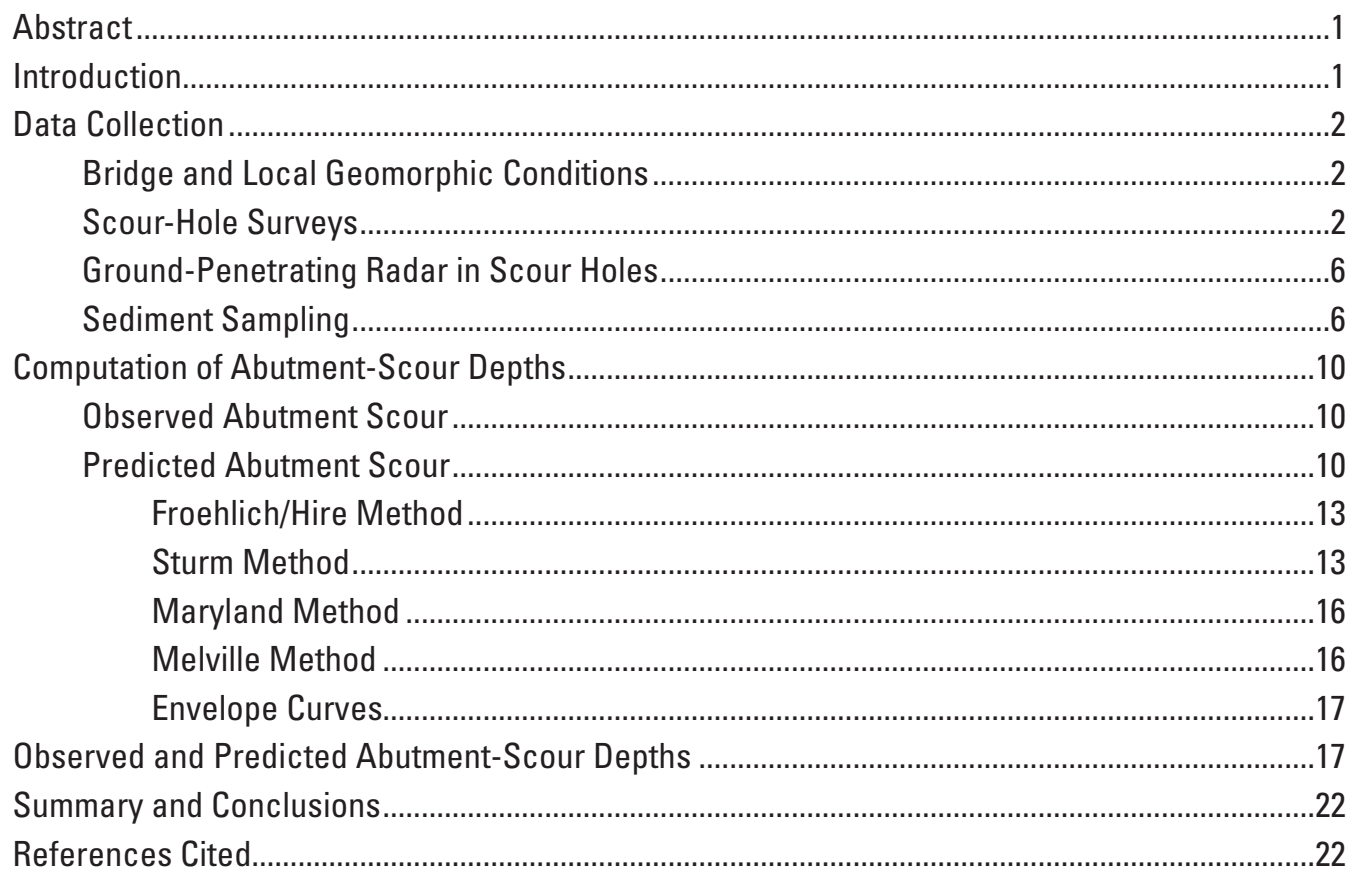

\section{Figures}

1. Map showing location of the 50 bridges in Maine evaluated for abutment scour............3

2. Photograph showing total station theodolite used to collect survey data at the East Branch of the Wesserunsett Stream at Athens, Maine, August 25, 2004

3. Diagram showing example of ground-penetrating radar output with inferred scour-hole infill, Little River at Windham, Maine

4-8. Graphs showing-

4. Relation of observed maximum abutment-scour depth to predicted maximum abutment-scour depth computed by the Froehlich/Hire method for 50 bridges in Maine.

5. Relation of observed maximum abutment-scour depths to predicted maximum abutment-scour depths computed by the Sturm method for 50 bridges in Maine.

6. Relation of observed maximum abutment-scour depths to predicted maximum abutment-scour depths computed by the Maryland method for 50 bridges in Maine.

7. Relation of observed maximum abutment-scour depths to predicted maximum abutment-scour depths computed by the Melville method for 50 bridges in Maine

8. Relation of observed maximum abutment-scour depth to the length of the active flow blocked by the bridge embankment at 50 bridges in Maine 


\section{Tables}

1. Location, age, and physical characteristics of 50 bridges in Maine evaluated for abutment scour.....

2. Variables used in abutment-scour prediction methods for 50 bridges in Maine..............8

3. Hydrologic information for 50 bridges in Maine evaluated for abutment scour ..............11

4. Predicted and observed maximum abutment-scour depths at 50 bridges in Maine .......14

5. Predicted maximum abutment-scour depth compared to observed maximum abutment-scour depth for 50 bridges in Maine.......

6. Correlations between predicted and observed maximum abutment-scour depths for 50 bridges in Maine

\section{Conversion Factors and Datum}

Inch/Pound to SI

\begin{tabular}{lcl}
\hline \multicolumn{1}{c}{ Multiply } & By & \multicolumn{1}{c}{ To obtain } \\
\hline inch (in.) & Length & \\
foot (ft) & 25.4 & millimeter $(\mathrm{mm})$ \\
mile (mi) & 0.3048 & meter $(\mathrm{m})$ \\
\hline & 1.609 & kilometer $(\mathrm{km})$ \\
\hline square mile $\left(\mathrm{mi}^{2}\right)$ & Area & \\
\hline & 2.590 & square kilometer $\left(\mathrm{km}^{2}\right)$ \\
\hline foot per second $(\mathrm{ft} / \mathrm{s})$ & Flow rate & \\
cubic foot per second $\left(\mathrm{ft}{ }^{3} / \mathrm{s}\right)$ & 0.3048 & meter per second $(\mathrm{m} / \mathrm{s})$ \\
\hline & 0.02832 & cubic meter per second $\left(\mathrm{m}^{3} / \mathrm{s}\right)$ \\
\hline pound (lb) & Mass & \\
\hline
\end{tabular}

Vertical coordinate information is referenced to the North American Vertical Datum of 1988 (NAVD 88).

Horizontal coordinate information is referenced to the North American Datum of 1983 (NAD 83). 


\title{
Comparison of Observed and Predicted Abutment Scour at Selected Bridges in Maine
}

\author{
By Pamela J. Lombard and Glenn A. Hodgkins
}

\section{Abstract}

Maximum abutment-scour depths predicted with five different methods were compared to maximum abutment-scour depths observed at 100 abutments at 50 bridge sites in Maine with a median bridge age of 66 years. Prediction methods included the Froehlich/Hire method, the Sturm method, and the Maryland method published in Federal Highway Administration Hydraulic Engineering Circular 18 (HEC-18); the Melville method; and envelope curves. No correlation was found between scour calculated using any of the prediction methods and observed scour. Abutment scour observed in the field ranged from 0 to 6.8 feet, with an average observed scour of less than 1.0 foot. Fifteen of the 50 bridge sites had no observable scour. Equations frequently overpredicted scour by an order of magnitude and in some cases by two orders of magnitude. The equations also underpredicted scour 4 to 14 percent of the time.

\section{Introduction}

Scour at bridge piers and at abutments are two of the leading causes of bridge failure nationwide (Barkdoll and others, 2006). Excessive abutment scour can cause high maintenance costs and (or) bridge collapse. Abutment scour is a problem in Maine that requires resources for maintenance, repair, and bridge replacement (J. Foster, Maine Department of Transportation, written commun., 2002). Accurate estimation of abutment scour and design of bridges to minimize scour are important for bridge safety and lower construction costs.

Most equations currently used to estimate abutment scour in the Froehlich/Hire method, the Sturm method, and the Maryland method from Hydraulic Engineering Circular 18 (HEC-18; Richardson and Davis, 2001), and the Melville method (Melville, 1997) were developed on the basis of experiments in the laboratory and have not been widely tested for field application. Only the Hire equation in the Froehlich/ Hire method was based on field data; it involved scour data at the end of spurs in the Mississippi River (Richardson and
Davis, 2001). The accuracy of these methods to predict abutment scour at bridges in Maine is unknown. A study conducted by the U.S. Geological Survey (USGS) to evaluate bridge pier scour in Maine found that HEC-18 pier-scour equations worked reasonably well as envelope equations for bridges in Maine, over-predicting scour by 0.7 to $18.3 \mathrm{ft}$, and rarely underpredicting scour (Hodgkins and Lombard, 2002).

Scour at bridge sites is generally divided into three components: aggradation or degradation of the river bed, contraction scour at the bridge, and local scour at the bridge piers or abutments. Aggradation and degradation are long-term streambed-elevation changes due to natural or man-induced processes. Contraction scour is a lowering of the streambed in the vicinity of the bridge that is caused by contracted widths at the bridge compared to natural widths upstream. Local scour is caused by an acceleration of flow due to obstructions such as piers or abutments. HEC-18 (Richardson and Davis, 2001) notes that abutments located at or near the channel banks (as opposed to abutments located in the floodplains) are most vulnerable to scour.

Conditions during scour can be clear-water or live-bed. Clear-water scour occurs where there is no movement of bed material into a scour hole during the time of scour. Live-bed scour occurs when there is movement of bed material during the time of scour that often fills or partially fills the scour hole during the falling stage of a flood hydrograph. Most abutmentscour estimation methods require a numerical determination of whether the scour is clear-water or live-bed to determine which equation should be applied.

To test methods that predict maximum abutment-scour depths for bridges in Maine, the USGS began a study in cooperation with the Maine Department of Transportation (MaineDOT) in 2003 to provide a quantitative evaluation of abutment-scour estimation methods that are currently used for designing bridges in Maine, and to evaluate additional methods that have the potential to more accurately predict abutment-scour depths. This report deals primarily with abutment scour; however, some analysis of contraction scour is presented where needed to separate contraction scour from abutment scour for methods that combine both types of scour. 


\section{Data Collection}

Bridges with spans of less than $130 \mathrm{ft}$, vertical wall abutments, wingwalls and a range of representative drainage areas and bed materials were selected across Maine for analysis in this study. The selected bridges represent the entire state except for the northwestern and far eastern portions. The absence of study sites in these two areas reflects the low density of roads and population. Ninety percent of the bridges had abutments that protruded into the channel. More than 300 bridges were visited and 50 (fig. 1, table 1) were selected for analysis according to the following criteria: the bridge was not in a tidal stream reach; the streambed was composed of erodible material as opposed to bedrock; the bridge did not span an interstate highway or otherwise unsafe working environment; and the bridge did not have regular known ice or debris jams. If a bridge had any evidence of repairs such as grout or riprap that had the potential to affect maximum scour, the bridge was not used for the study. The widths of the openings of the selected bridges ranged from 12.7 to $126 \mathrm{ft}$. Most bridges had widths between 15 and $65 \mathrm{ft}$. Embankments and abutments were in line with the flow or were skewed up to 50 degrees from the flow (table 1).

\section{Bridge and Local Geomorphic Conditions}

Bridges were surveyed with a total station theodolite during the summer low-flow seasons of 2003, 2004, and 2005 to determine bridge and channel geometry and characteristics, and to measure the observed abutment scour relative to a local datum. The geometry of the channel and bridge was defined by field surveys of the structure and four local cross sections following established surveying guidelines (Benson and Dalrymple, 1968). Cross sections surveyed with a total station theodolite included an approach cross section in the natural, unconstricted channel approximately one bridge-width upstream from the bridge; an upstream bridge-face cross section; a downstream bridge-face cross section; and an exit cross section approximately one bridge-width downstream from the bridge, defining the unconstricted downstream channel conditions. A photograph of a typical bridge used for this study is shown in figure 2. Other information collected included elevations of the top of the road and lengths of wingwalls, abutments, and embankments. Roughness factors (Manning's " $n$ ") for the main channel and floodplains were estimated from field observations guided by USGS publications (U.S. Geological Survey, 1989; 1998).

\section{Scour-Hole Surveys}

Local scour holes in the vicinity of the abutments, defined in comparison to the surface of the streambed in the areas immediately surrounding them, were surveyed with a total station theodolite or measured down from a surveyed water surface. The maximum depth of each scour hole was measured. In cases where more than one scour hole was found at a bridge site, all scour areas were defined. The streambed surface judged to be the most relevant reference-surface elevation (the best estimate of the streambed-surface elevation just outside a scour hole) was also surveyed for each scour hole. This elevation was a reference surface for the abutment scour only and any contraction scour that had occurred at the site was assumed to have occurred evenly across the section (affected the reference surface and the abutment scour hole uniformly). 


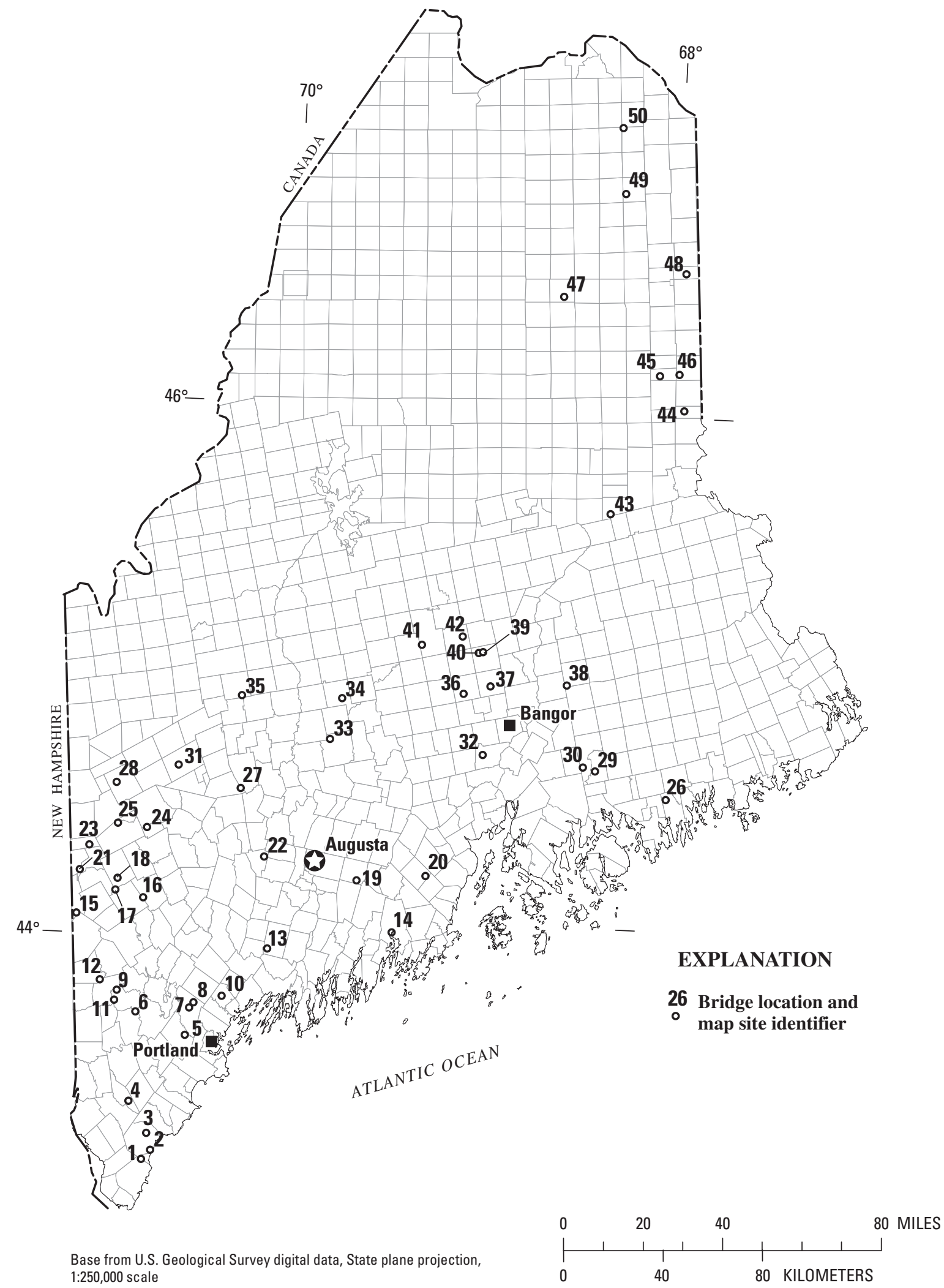

Figure 1. Location of the 50 bridges in Maine evaluated for abutment scour. 
Table 1. Location, age, and physical characteristics of 50 bridges in Maine evaluated for abutment scour.

\begin{tabular}{|c|c|c|c|c|c|c|c|c|}
\hline $\begin{array}{l}\text { Map site } \\
\text { identifier }\end{array}$ & Stream name and town & Road crossing & $\begin{array}{c}\text { Longitude } \\
\text { (decimal } \\
\text { degrees) }\end{array}$ & $\begin{array}{l}\text { Latitude } \\
\text { (decimal } \\
\text { degrees) }\end{array}$ & $\begin{array}{c}\text { Bridge } \\
\text { age } \\
\text { (years) }\end{array}$ & $\begin{array}{l}\text { Embank- } \\
\text { ment skew } \\
\text { to flow } \\
\text { (degrees) }\end{array}$ & $\begin{array}{l}\text { Abutment } \\
\text { skew to } \\
\text { flow } \\
\text { (degrees) }\end{array}$ & $\begin{array}{c}\text { Width of } \\
\text { bridge } \\
\text { opening } \\
\text { (feet) }\end{array}$ \\
\hline 1 & Ogunquit River at Ogunquit & North Village Road & -70.6303 & 43.2651 & 48 & 0 & 20 & 23.6 \\
\hline 2 & Webhannet River at Wells & Route 1 & -70.5875 & 43.2984 & 74 & 30 & 30 & 14.7 \\
\hline 3 & Merriland River at Wells & Route 9A & -70.6087 & 43.3597 & 55 & 25 & 0 & 27.0 \\
\hline 4 & Littlefield River at Alfred & Route 111 & -70.7009 & 43.4756 & 73 & 0 & 0 & 24.8 \\
\hline 5 & Little River at Gorham & Route 202 & -70.4242 & 43.7208 & 54 & 8 & 10 & 54.3 \\
\hline 6 & Quaker Brook at East Baldwin & Route 113 & -70.6753 & 43.8017 & 67 & 0 & 0 & 20.0 \\
\hline 7 & Pleasant River at Windham & William Knight Road & -70.4036 & 43.8207 & 38 & 25 & 0 & 22.5 \\
\hline 8 & Pleasant River at Windham & Route 202 & -70.3832 & 43.8385 & 57 & 0 & 0 & 21.5 \\
\hline 9 & Breakneck Brook at Baldwin & Route 113 & -70.7836 & 43.8439 & 47 & 0 & 0 & 48.0 \\
\hline 10 & Royal River at North Yarmouth & Route 231 & -70.2400 & 43.8647 & 79 & 10 & 10 & 48.3 \\
\hline 11 & Hancock Brook at Hiram & Sebago Road & -70.7711 & 43.8792 & 64 & 40 & 5 & 35.3 \\
\hline 12 & Tenmile River at Brownfield & Old Route 5/113 & -70.8561 & 43.9167 & 85 & 20 & 20 & 15.0 \\
\hline 13 & Gillespie Brook at Bowdoin & Route 125 & -70.0144 & 44.0397 & 66 & 20 & 0 & 12.7 \\
\hline 14 & Medomak River at Waldoboro & Route 1 & -69.3850 & 44.1014 & 71 & 23 & 17 & 113.0 \\
\hline 15 & Little Cold River at Stow & Route 113 & -70.9823 & 44.1586 & 65 & 25 & 45 & 40.0 \\
\hline 16 & Meadow Brook at Norway & Route 118 & -70.6470 & 44.2190 & 80 & 25 & 25 & 18.6 \\
\hline 17 & Crooked River at Albany Township (1) & Route 5 & -70.7870 & 44.2450 & 41 & 35 & 0 & 48.2 \\
\hline 18 & Crooked River at Albany Township (2) & Route $5 / 35$ & -70.7780 & 44.2880 & 70 & 30 & 10 & 23.9 \\
\hline 19 & $\begin{array}{l}\text { West Branch Sheepscot River at } \\
\text { Windsor }\end{array}$ & Maxcys Mill Road & -69.5652 & 44.2904 & 50 & 0 & 0 & 25.8 \\
\hline 20 & Saint George River at Appleton & Route 105 & -69.2153 & 44.3077 & 50 & 7 & 7 & 57.0 \\
\hline 21 & Stony Brook at Batchelders Grant & Route 113 & -70.9698 & 44.3160 & 70 & 0 & 0 & 46.0 \\
\hline 22 & Lovejoy Pond Outlet Stream at Wayne & North Pond Road & -70.0345 & 44.3744 & 72 & 25 & 25 & 22.0 \\
\hline 23 & Whites Brook at Gilead & North Road & -70.9260 & 44.4020 & 76 & 30 & 30 & 14.9 \\
\hline 24 & Concord Brook at Rumford & South Rumford Road & -70.6330 & 44.4750 & 75 & 25 & 0 & 35.8 \\
\hline 25 & Stony Brook at Hanover & Route $2 / 5$ & -70.7830 & 44.4880 & 76 & 15 & 25 & 18.4 \\
\hline 26 & Tunk Stream at Steuben & Unionville Road & -67.9896 & 44.5803 & 51 & 45 & 20 & 23.4 \\
\hline 27 & Wilson Stream at Farmington & Route 133 & -70.1603 & 44.6228 & 66 & 30 & 0 & 50.6 \\
\hline 28 & Stony Brook at Andover & East B Hill Road & -70.7933 & 44.6374 & 52 & 55 & 55 & 25.1 \\
\hline 29 & Webb Brook at Waltham & Route 179 & -68.3494 & 44.6875 & 69 & 20 & 20 & 23.2 \\
\hline 30 & Tannery Brook at Waltham & Route 181 & -68.4126 & 44.7012 & 66 & 15 & 15 & 22.8 \\
\hline 31 & West Brook at Weld & West Road & -70.4791 & 44.7055 & 50 & 5 & 5 & 35.2 \\
\hline 32 & $\begin{array}{l}\text { West Branch Souadabscook River at } \\
\text { Hampden }\end{array}$ & Route $202 / 9$ & -68.9242 & 44.7489 & 52 & 40 & 10 & 44.6 \\
\hline 33 & $\begin{array}{l}\text { West Branch Wesserunsett Stream at } \\
\text { Skowhegan }\end{array}$ & Hilton Hill Road & -69.7050 & 44.8050 & 71 & 35 & 6 & 38.2 \\
\hline 34 & $\begin{array}{l}\text { East Branch Wessurunsett Stream at } \\
\text { Athens }\end{array}$ & Route 150 & -69.6457 & 44.9548 & 41 & 33 & 45 & 60.0 \\
\hline 35 & $\begin{array}{l}\text { West Branch Carrabassett River at } \\
\text { Kingfield }\end{array}$ & Route 27 & -70.1600 & 44.9610 & 82 & 10 & 10 & 63.0 \\
\hline 36 & Paul Brook at Corinth & West Corinth Road & -69.0212 & 44.9715 & 51 & 10 & 0 & 63.0 \\
\hline 37 & Pushaw Stream at Hudson & Route 221/43 & -68.8841 & 44.9985 & 64 & 45 & 35 & 17.6 \\
\hline 38 & Sunkhaze Stream at Greenfield & County Road & -68.4910 & 45.0011 & 49 & 45 & 32 & 20.4 \\
\hline 39 & West Branch Dead Stream at Bradford & Lagrange Road & -68.9425 & 45.1206 & 52 & 20 & 20 & 16.8 \\
\hline 40 & $\begin{array}{l}\text { Middle Branch Dead Stream at } \\
\text { Bradford }\end{array}$ & Lagrange Road & -68.9206 & 45.1236 & 68 & 35 & 30 & 18.8 \\
\hline
\end{tabular}


Table 1. Location, age, and physical characteristics of 50 bridges in Maine evaluated for abutment scour.-Continued

\begin{tabular}{|c|c|c|c|c|c|c|c|c|}
\hline $\begin{array}{l}\text { Map site } \\
\text { identifier }\end{array}$ & Stream name and town & Road crossing & $\begin{array}{c}\text { Longitude } \\
\text { (decimal } \\
\text { degrees) }\end{array}$ & $\begin{array}{l}\text { Latitude } \\
\text { (decimal } \\
\text { degrees) }\end{array}$ & $\begin{array}{c}\text { Bridge } \\
\text { age } \\
\text { (years) }\end{array}$ & $\begin{array}{l}\text { Embank- } \\
\text { ment skew } \\
\text { to flow } \\
\text { (degrees) }\end{array}$ & $\begin{array}{l}\text { Abutment } \\
\text { skew to } \\
\text { flow } \\
\text { (degrees) }\end{array}$ & $\begin{array}{l}\text { Width of } \\
\text { bridge } \\
\text { opening } \\
\text { (feet) }\end{array}$ \\
\hline 41 & Black Stream at Dover-Foxcroft & Route 7 & -69.2361 & 45.1506 & 29 & 30 & 40 & 18.2 \\
\hline 42 & Alder Stream at Atkinson & Atkinson Road & -69.0253 & 45.1817 & 42 & 0 & 0 & 24.5 \\
\hline 43 & Macwahoc Stream at Macwahoc & Route 170 & -68.2589 & 45.6242 & 85 & 20 & 20 & 37.0 \\
\hline 44 & $\begin{array}{l}\text { South Branch Meduxnekeag River at } \\
\text { Cary Plantation }\end{array}$ & Horseback Road & -67.8661 & 45.9967 & 50 & 28 & 10 & 32.8 \\
\hline 45 & Dunn Brook at New Limerick & Route 2 & -67.9917 & 46.1250 & 86 & 40 & 10 & 29.3 \\
\hline 46 & Moose Brook at Houlton & County Road & -67.8903 & 46.1292 & 80 & 50 & 50 & 20.0 \\
\hline 47 & Umcolcus Stream at Oxbow Plantation & Oxbow Road & -68.4914 & 46.4186 & 50 & 20 & 20 & 17.6 \\
\hline 48 & Prestile Stream at Blaine & Pierce Road & -67.8453 & 46.4958 & 47 & 20 & 20 & 44.2 \\
\hline 49 & Salmon Brook at Washburn & Route 228 & -68.1583 & 46.7908 & 79 & 15 & 15 & 53.0 \\
\hline 50 & $\begin{array}{l}\text { Little Madawaska Stream at } \\
\text { Stockholm }\end{array}$ & Old Route 161 & -68.1694 & 47.0303 & 75 & 0 & 0 & 23.7 \\
\hline
\end{tabular}

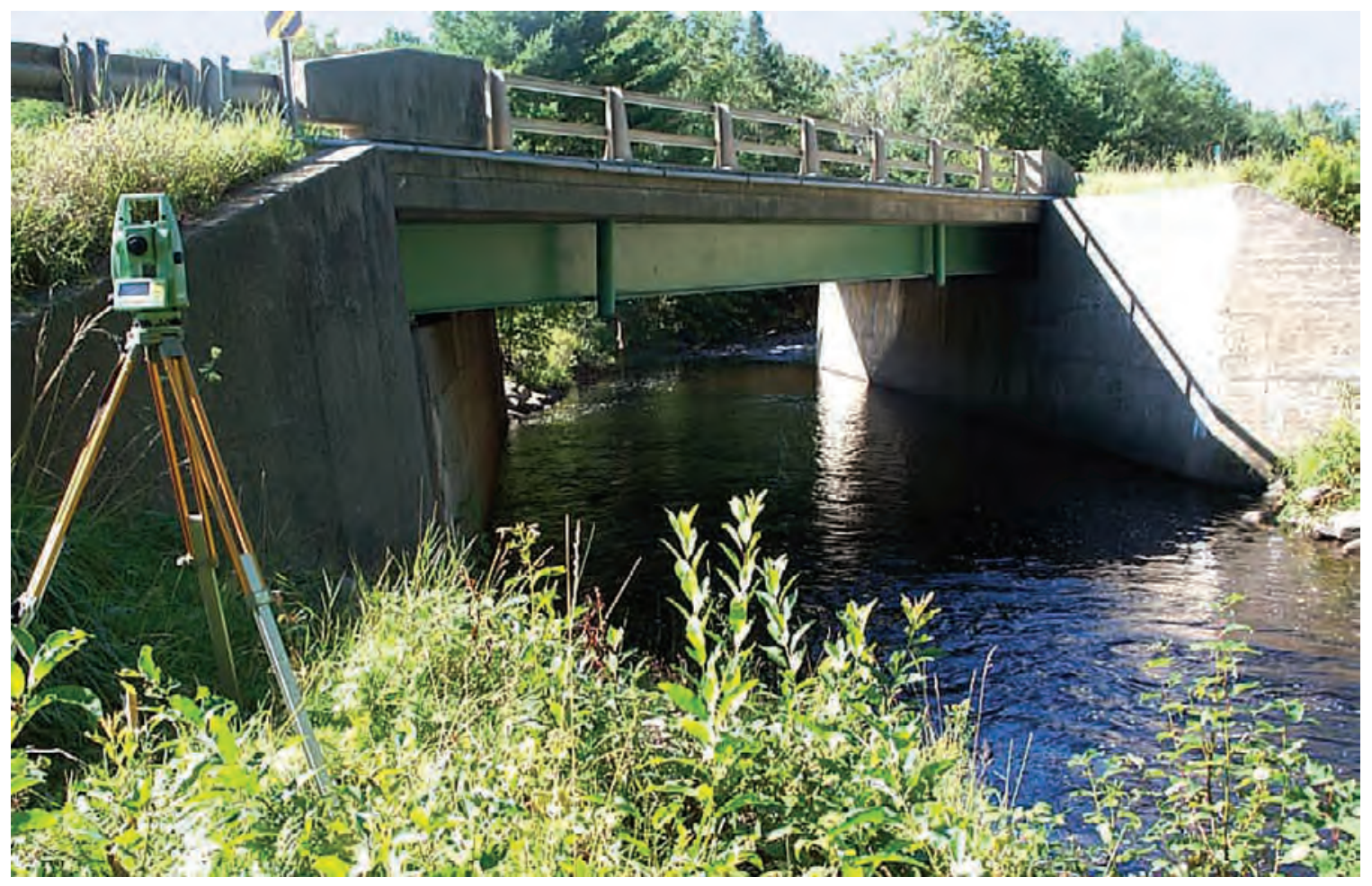

Figure 2. Total station theodolite used to collect survey data at the East Branch of the Wesserunsett Stream at Athens, Maine, August 25, 2004. 


\section{Ground-Penetrating Radar in Scour Holes}

It is possible for scour holes to be refilled with bed material — particularly fine-grained materials — on flood hydrograph recessions or during subsequent floods. Groundpenetrating radar (GPR) was used to look for infilled scour holes; all bridges with abutment scour holes greater than $1.0 \mathrm{ft}$ in depth and with fine materials (sand or silt) in the scour hole were checked. Fifteen of the sites that had visible scour were evaluated with GPR. Eight of the 15 were evaluated on one abutment and 7 on both abutments, for a total of 22 GPR measurements. It was assumed that bridges with small (less than $1.0 \mathrm{ft}$ ) or non-existent scour holes were not likely to have large infilled scour holes. Several years of pier and abutment scour observations in Maine have shown that scour holes typically do not infill substantially.

Materials in abutment scour holes are not necessarily the same size as materials upstream from the hole. Bed-material sizes upstream from the hole are used in the computation of abutment-scour depths for any methods that use bed-material size (see next section on sediment sampling). If scour holes have refilled with bed material of approximately the same size distribution as the areas surrounding the hole, infill cannot be detected.

Infilled scour holes were found at several sites; figure 3 is an example of GPR output with inferred scourhole infill. Multiple passes were made over each scour hole at a frequency of 100 megahertz. The GPR data were verified by driving a metal rod through the fine sediments at multiple points in scour holes; a difference in resistance indicated a change of bed material (typically a change from sand to stones).

\section{Sediment Sampling}

Bed-material size (median and (or) maximum grain size) is a variable in some of the abutment-scour prediction methods. Particle-size distribution was used to characterize bed material in the main channel upstream from each bridge. A representative sample of bed material was obtained by grid sampling for beds with predominantly coarse-grained sediments (greater than $2 \mathrm{~mm}$ ), and bulk sampling for beds with predominantly fine-grained sediments (less than $2 \mathrm{~mm}$ ) (Hayes, 1993). Sediment sampling was conducted in the summers of 2005 and 2006.

Grid sampling was conducted in lines perpendicular to the stream near the approach cross section. Parallel lines spaced $10 \mathrm{ft}$ apart were sampled until 100 samples were collected. Samples were collected at even intervals of approximately twice the b-axis (a-axis is the longest dimension of cobbles/gravel, b-axis is the middle dimension, and c-axis is the shortest dimension) of the largest diameter stone in the sampling area. Each particle collected was classified according to the largest opening through which it would not pass in a template made up of 15 size classes from 2 to $180 \mathrm{~mm}$. For particles with a b-axis greater than $180 \mathrm{~mm}$, the b-axis was measured. Each sample was distributed into size classes from which a median grain size $\left(\mathrm{D}_{50}\right)$ and maximum grain size $\left(\mathrm{D}_{\max }\right)$ were calculated (table 2).

For the 10 bridge sites with predominantly sand or silt bed materials, methods were used as in Hayes (1993), which were modifications of methods described in Ashmore and others (1988) and International Organization for Standardization (1977). Composite bulk samples were obtained using a US BMH-60 bed-material sampler (Edwards and Glysson, 1999). Five replicate samples were collected and combined from three locations (approximately 25, 50, and 75 percent of the cross-section width) in the approach cross section, and at equivalent locations in cross sections upstream and downstream from the approach cross section. Bulk samples were analyzed at the MaineDOT soils laboratory by sorting and weighing using American Association of State Highway and Transportation Officials (AASHTO) T27 sieve analyses (American Association of State Highway and Transportation Officials, 2001) from which $\mathrm{D}_{50}$ and $\mathrm{D}_{\max }$ were obtained (table 2). 


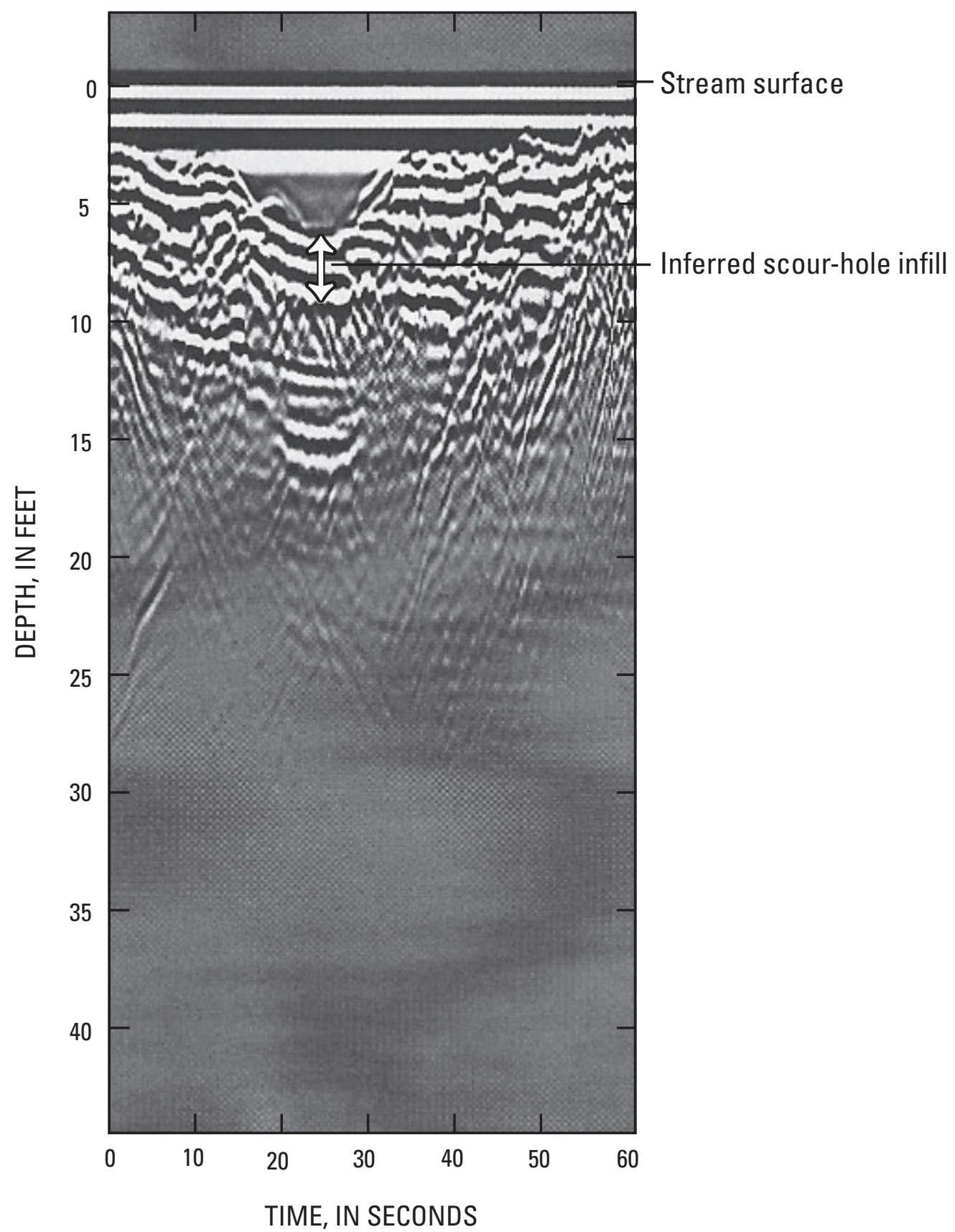

Figure 3. Example of ground-penetrating radar output with inferred scour-hole infill, Little River at Windham, Maine. 


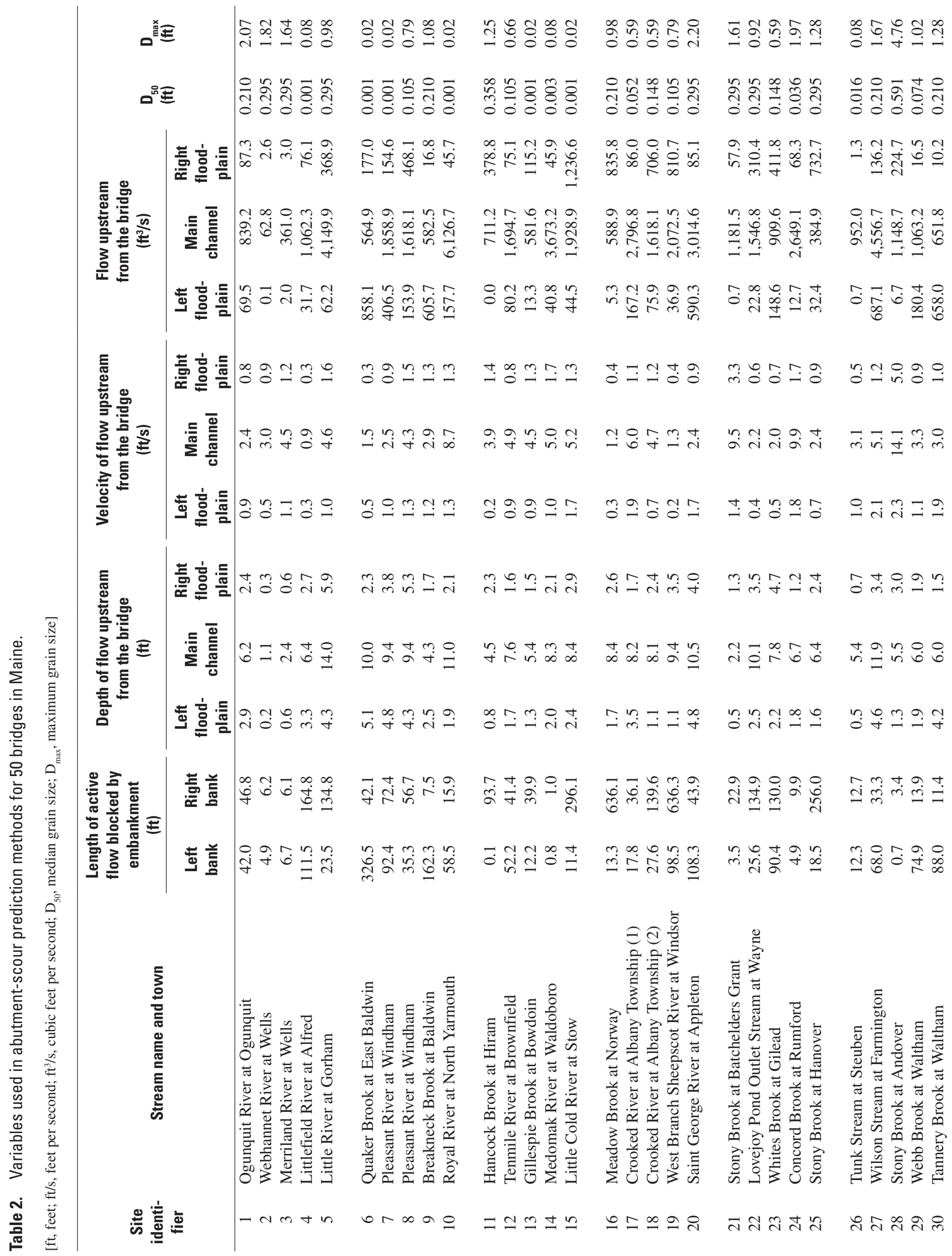




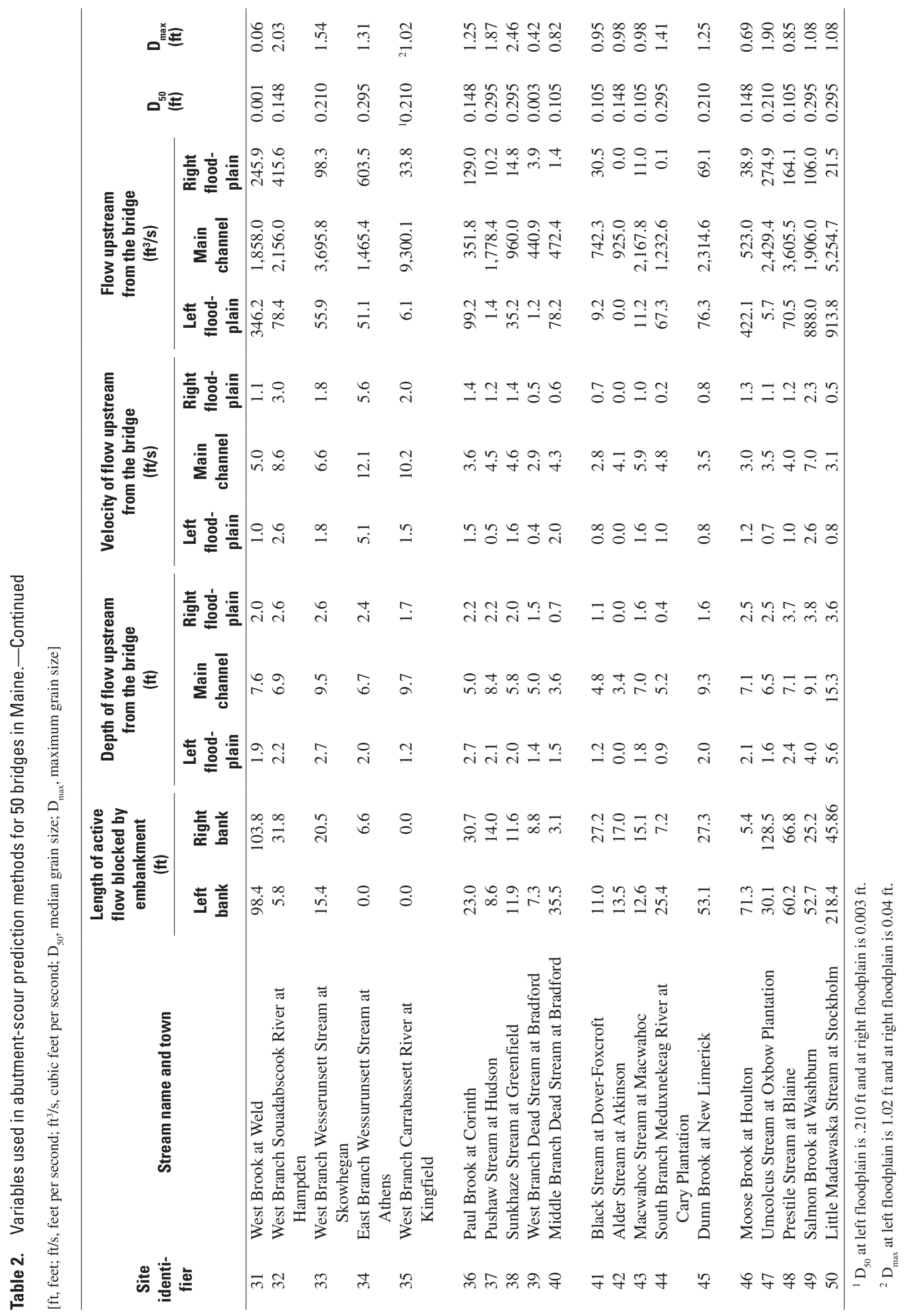




\section{Computation of Abutment-Scour Depths}

Maximum abutment-scour depths predicted with five different methods were compared to maximum abutment-scour depths observed at 100 abutments at 50 bridge sites in Maine. Observed maximum scour depth elevations were surveyed directly or measured down from a surveyed water surface. Scour-prediction variables needed for the 5 prediction methods were obtained from one-dimensional hydraulic models developed from surveyed elevation data collected in the field.

\section{Observed Abutment Scour}

Observed maximum abutment-scour depths for the 50 bridges in this study were calculated by computing the difference between the maximum abutment-scour depth elevations and the bed reference surface elevations for each abutment. Bed reference surface elevations were defined as areas of relatively uniform elevation in the immediate vicinity of the scour hole, and outside the influence of the scour hole.

Any additional scour observed from ground-penetrating radar was added to the maximum observed scour depth. It is possible that the total observed abutment scour does not include infilled scour holes in certain situations (see "Ground Penetrating Radar in Scour Holes" section for details).

\section{Predicted Abutment Scour}

Predicted scour was computed with five different methods. The results of these methods were compared to observed scour at 50 sites. Methods that are currently used by MaineDOT to predict abutment scour were tested, as well as a few additional methods that had the potential to better predict maximum abutment scour in Maine: the Froelich/Hire method, the Sturm method, the Maryland method (Richardson and Davis, 2001), the Melville method (Melville, 1997), and a method consisting of correlations between observed abutmentscour depths and individual bridge and (or) hydraulic variables from this study, from which envelope curves could be created. The envelope curve method has been used successfully to predict abutment-scour depths at bridges in South Carolina (Benedict, 2003). Variables for the tested equations were determined from data collected in the field and from the U.S. Army Corps of Engineers step-backwater computer program HEC-RAS (U.S. Army Corps of Engineers, 2001).

Several variables are used in more than one of the abutment-scour prediction methods tested in this report: the abutment skew to flow; the length of active flow that blocks the embankment (projected normal to flow); and the depth, velocity, and flow in the cross section one bridge-width upstream from the bridge (the approach cross section) (tables 1 and 2). Several of the variables are similar, but not identical, in the different methods. For example, the depth of flow can be the average depth of flow in the floodplain of the approach cross section or in the main channel of the approach cross section (as in the Melville method); the average depth of flow in the portion of the approach cross section blocked by the embankment (as in the Froehlich equation); or the depth of flow at the abutment prior to scour (as in the Hire equation). If a depth at the abutment prior to scour is required, it was estimated as the average depth of flow in either the main channel of the approach or in the floodplain of the approach - depending on whether the abutment is in the main channel or the floodplain of the bridge cross section, respectively.

Because field measurements of scour holes were made during non-flood conditions, the hydrologic and hydraulic conditions that caused the scour are unknown and must be estimated. The scour-producing flow is estimated from the age of the bridge. The peak flow with a 50-percent chance of occurring during the life of the bridge is the flow that is assumed to have caused the scour. For example, there is a 50-percent chance that a flow with a recurrence interval of 73 years will occur over the life of a 50 -year-old bridge using the standard risk equation $T=1 /\left(1-0.5^{(1 / y)}\right)$, where $y$ is the age of the bridge and $T$ is the recurrence interval of the flood (Bedient and Huber, 1988). The flow for the calculated return interval is interpolated from flows of standard return intervals calculated with regression equations, such as the 100- and 500-year regression equations developed for Maine (Hodgkins, 1999) (table 3).

Very few continuous-record streamflow-gaging stations in Maine have both a drainage area in the same size range as those of the abutment-scour sites (less than $100 \mathrm{mi}^{2}$ ) and a record greater than 50 years. Two gaging stations have more than 50 years of record and drainage areas of less than $100 \mathrm{mi}^{2}$, and six additional sites have more than 50 years of record and drainage areas of 100 to $200 \mathrm{mi}^{2}$. The recurrence intervals of certain historical floods in Maine have not always shown a strong correlation between sites that are geographically near one another, especially if drainage areas differ greatly in size. Therefore, recorded site-specific peak-flow information was not used to estimate peak flows for the sites in the current study.

Estimated recurrence intervals varied from 40 to 125 years depending on the age of the bridge (in most cases, bridge age was greater than 50 years). The median recurrence interval was 96 years. In the last 50 years, one of the eight small continuously gaged stations had a peak flow with a recurrence interval between 25 and 50 years, one had a peak flow with a recurrence interval between 50 and 100 years, and the rest had peak flows with recurrence intervals greater than 100 years. Therefore, peak flows with the estimated recurrence intervals had a reasonable likelihood of occurring at sites in the current study during the life of most of the bridges.

Hydraulic variables used to estimate abutment scour at a site using the methods in this report, such as flow depths and velocities, were generated with U.S. Army Corps of Engineers Hydrologic Engineering Center River Analysis System (HEC-RAS) software (U.S. Army Corps of Engineers, 
Table 3. Hydrologic information for 50 bridges in Maine evaluated for abutment scour.

[Peak flow, flow that is assumed to have caused scour based on the age of the bridge; $\mathrm{ft}^{3} / \mathrm{s}$, cubic feet per second]

\begin{tabular}{|c|c|c|c|c|c|c|}
\hline $\begin{array}{c}\text { Site } \\
\text { identifier }\end{array}$ & Stream name and town & $\begin{array}{l}\text { Slope in } \\
\text { vicinity of } \\
\text { bridge }\end{array}$ & $\begin{array}{c}\text { Drainage } \\
\text { basin } \\
\text { (square miles) }\end{array}$ & $\begin{array}{l}\text { Wetlands } \\
\text { (percent) }\end{array}$ & $\begin{array}{l}\text { Estimated recurrence } \\
\text { interval of peak flow } \\
\text { (years) }\end{array}$ & $\begin{array}{c}\text { Estimated } \\
\text { peak flow } \\
\left(\mathrm{ft}^{3} / \mathrm{s}\right)\end{array}$ \\
\hline 1 & Ogunquit River at Ogunquit & 0.004 & 11.8 & 0.1 & 69.8 & 996 \\
\hline 2 & Webhannet River at Wells & 0.003 & 5.3 & 0.4 & 107.3 & 65 \\
\hline 3 & Merriland River at Wells & 0.002 & 12.6 & 0.3 & 79.8 & 366 \\
\hline 4 & Littlefield River at Alfred & 0.001 & 21.9 & 0.2 & 105.8 & 1,167 \\
\hline 6 & Quaker Brook at East Baldwin & 0.004 & 11.0 & 0.1 & 97.2 & 1,595 \\
\hline 7 & Pleasant River at Windham & 0.001 & 24.0 & 0.1 & 55.3 & 2,420 \\
\hline 8 & Pleasant River at Windham & 0.006 & 20.5 & 0.1 & 82.7 & 2,240 \\
\hline 9 & Breakneck Brook at Baldwin & 0.011 & 5.0 & 0.0 & 68.3 & 1,205 \\
\hline 12 & Tenmile River at Brownfield & 0.002 & 12.8 & 0.1 & 123.1 & 1,849 \\
\hline 13 & Gillespie Brook at Bowdoin & 0.005 & 6.7 & 0.1 & 95.7 & 710 \\
\hline 14 & Medomak River at Waldoboro & 0.034 & 78.6 & 0.2 & 102.9 & 3,765 \\
\hline 15 & Little Cold River at Stow & 0.003 & 14.9 & 0.0 & 94.3 & 3,206 \\
\hline 16 & Meadow Brook at Norway & 0.001 & 7.3 & 0.0 & 115.9 & 1,430 \\
\hline 17 & Crooked River at Albany Township (1) & 0.001 & 28.5 & 0.1 & 59.7 & 3,052 \\
\hline 18 & Crooked River at Albany Township (2) & 0.003 & 19.0 & 0.1 & 101.5 & 2,400 \\
\hline 19 & West Branch Sheepscot River at Windsor & 0.002 & 42.9 & 0.1 & 72.6 & 2,924 \\
\hline 20 & Saint George River at Appleton & 0.001 & 95.1 & 0.2 & 72.6 & 3,692 \\
\hline 26 & Tunk Stream at Steuben & 0.001 & 32.8 & 0.2 & 74.1 & 954 \\
\hline 27 & Wilson Stream at Farmington & 0.001 & 51.9 & 0.1 & 95.7 & 5,381 \\
\hline 28 & Stony Brook at Andover & 0.031 & 5.7 & 0.0 & 75.5 & 1,384 \\
\hline 29 & Webb Brook at Waltham & 0.035 & 38.2 & 0.2 & 100.0 & 1,264 \\
\hline 30 & Tannery Brook at Waltham & 0.012 & 18.2 & 0.1 & 95.7 & 1,325 \\
\hline 31 & West Brook at Weld & 0.002 & 15.4 & 0.0 & 72.6 & 2,454 \\
\hline 32 & West Branch Souadabscook River at Hampden & 0.006 & 27.2 & 0.1 & 75.5 & 2,649 \\
\hline 33 & West Branch Wesserunsett Stream at Skowhegan & 0.025 & 54.3 & 0.1 & 102.9 & 3,846 \\
\hline 34 & East Branch Wessurunsett Stream at Athens & 0.012 & 18.5 & 0.1 & 59.7 & 2,116 \\
\hline 35 & West Branch Carrabassett River at Kingfield & 0.004 & 78.8 & 0.0 & 118.8 & 9,338 \\
\hline
\end{tabular}


Table 3. Hydrologic information for 50 bridges in Maine evaluated for abutment scour.-Continued

[Peak flow, flow that is assumed to have caused scour based on the age of the bridge; $\mathrm{ft}^{3} / \mathrm{s}$, cubic feet per second]

\begin{tabular}{|c|c|c|c|c|c|c|}
\hline $\begin{array}{c}\text { Site } \\
\text { identifier }\end{array}$ & Stream name and town & $\begin{array}{c}\text { Slope in } \\
\text { vicinity of } \\
\text { bridge }\end{array}$ & $\begin{array}{c}\text { Drainage } \\
\text { basin } \\
\text { (square miles) }\end{array}$ & $\begin{array}{l}\text { Wetlands } \\
\text { (percent) }\end{array}$ & $\begin{array}{l}\text { Estimated recurrence } \\
\text { interval of peak flow } \\
\text { (years) }\end{array}$ & $\begin{array}{c}\text { Estimated } \\
\text { peak flow } \\
\left(\mathrm{ft}^{3} / \mathrm{s}\right)\end{array}$ \\
\hline 36 & Paul Brook at Corinth & 0.001 & 7.1 & 0.1 & 74.1 & 580 \\
\hline 37 & Pushaw Stream at Hudson & 0.032 & 46.7 & 0.2 & 92.8 & 1,789 \\
\hline 38 & Sunkhaze Stream at Greenfield & 0.007 & 16.0 & 0.2 & 71.2 & 1,007 \\
\hline 39 & West Branch Dead Stream at Bradford & 0.001 & 16.4 & 0.3 & 75.5 & 446 \\
\hline 40 & Middle Branch Dead Stream at Bradford & 0.005 & 7.9 & 0.2 & 98.6 & 552 \\
\hline 41 & Black Stream at Dover-Foxcroft & 0.002 & 26.7 & 0.2 & 42.3 & 782 \\
\hline 42 & Alder Stream at Atkinson & 0.004 & 32.7 & 0.2 & 61.1 & 925 \\
\hline 43 & Macwahoc Stream at Macwahoc & 0.002 & 57.7 & 0.2 & 123.1 & 2,188 \\
\hline 44 & $\begin{array}{l}\text { South Branch Meduxnekeag River at } \\
\text { Cary Plantation }\end{array}$ & 0.001 & 46.0 & 0.2 & 72.6 & 1,307 \\
\hline 45 & Dunn Brook at New Limerick & 0.012 & 17.6 & 0.1 & 124.6 & 2,459 \\
\hline 46 & Moose Brook at Houlton & 0.006 & 15.6 & 0.2 & 115.9 & 984 \\
\hline 47 & Umcolcus Stream at Oxbow Plantation & 0.002 & 82.4 & 0.2 & 72.6 & 2,711 \\
\hline 48 & Prestile Stream at Blaine & 0.001 & 88.5 & 0.2 & 68.3 & 3,839 \\
\hline 49 & Salmon Brook at Washburn & 0.017 & 29.5 & 0.1 & 114.5 & 2,904 \\
\hline 50 & Little Madawaska Stream at Stockholm & 0.001 & 84.6 & 0.1 & 108.7 & 6,188 \\
\hline
\end{tabular}

2001). Surveyed geometric data and Manning's roughness factors for cross sections at each bridge were entered into HEC-RAS. Site hydrologic characteristics (peak flows of a given recurrence interval, $T$ ) were also entered. The onedimensional steady-flow water-surface-profile computation component of HEC-RAS was used in the analysis. In addition to the computed $T$-year recurrence-interval flow, a range of flows (with recurrence intervals from 2 to 500 years) was modeled as part of the calibration to test the functionality of the model. Although hydraulic variables generated from one-dimensional HEC-RAS models are estimates and are an additional source of error, the large sample size of 50 bridges makes the evaluation of the scour equations with estimated variables useful. Furthermore, in a similar study comparing observed and predicted abutment-scour depths, Wagner and others (2006) determined that the abutment-scour equations were a larger source of error than the model used to estimate hydraulic variables.

Values of variables used in the abutment-scour methods are sensitive to the location of the channel bank points, those points that define the top of the stream channel. In Maine, the transition between the main channel and the floodplain is not always indicated by a clear break in slope. To determine channel bank locations, the break in slope nearest to the 2-year recurrence-interval flow was chosen. If the break in slope was not clear, the edge of the main channel was defined as the intersection of the water surface of the 2-year recurrenceinterval flow with the bed surface.

Although summaries of the tested methods are given below, the original sources of the equations (Richardson and Davis, 2001; Melville, 1997) should be consulted if the user wishes to calculate scour. The description of the methods below is not sufficiently comprehensive for use in estimating abutment-scour depths. In equations where predicted depths of abutment scour in the equations combine abutment scour and contraction scour (Sturm and Maryland methods, below), an equation for contraction scour developed by Laursen and described in HEC-18 (Richardson and Davis, 2001) was used to subtract contraction scour from the combined scour. 


\section{Froehlich/Hire Method}

Predicting abutment scour with the Froehlich equation or with the Hire equation is referred to in this report as the Froehlich/Hire method. The Froehlich equation (Richardson and Davis, 2001) can be used for either live-bed or clear-water scour. It is distinguished by its inclusion of the length of active flow obstructed by the embankment $\left(L^{\prime}\right) . L^{\prime}$ is projected normal to flow using the angle of the embankments to the flow. Although calculation of $L^{\prime}$ depends on the calculation of equal conveyance tubes in the approach cross section, the current version of HEC-RAS (3.1.3) does not compute tubes of equal conveyance, but rather slices of equal width. The first slice with a hydraulic depth greater than $1.5 \mathrm{ft}$ or a velocity greater than $1 \mathrm{ft} / \mathrm{s}$ marked the beginning of active flow in the overbank for the computation of $L^{\prime}$ in this report. The Froehlich equation is expected to overpredict scour, especially if the areas adjacent to the abutments are well vegetated (Richardson and Davis, 2001). The Froehlich equation is defined as:

$$
\frac{y_{s}}{y_{a}}=2.27 K_{1} K_{2}\left[\frac{L^{\prime}}{y_{a}}\right]^{0.43} F r^{0.61}+1,
$$

where

$$
\begin{gathered}
y_{s} \quad \begin{array}{c}
\text { is the depth of abutment scour at the abutment } \\
\text { (feet below streambed surface); }
\end{array} \\
y_{a} \quad \text { is the average depth of flow blocked by the } \\
\text { embankment in the approach (feet); } \\
K_{1} \quad \text { is a coefficient for the abutment shape; } \\
K_{2} \quad \text { is a coefficient for the angle of the } \\
\text { embankment to the flow; } \\
L^{\prime} \quad \text { is the length of active flow blocked by the } \\
\text { embankment, and projected normal to flow } \\
\text { (feet); and } \\
F r \quad \text { is the Froude number of the approach flow } \\
\text { upstream from the abutment. }
\end{gathered}
$$

In cases where the ratio of the length of total flow blocked by the embankment $(L)$ to the depth of flow at the abutment prior to scour $\left(y_{1}\right)$ is greater than 25 , the Hire equation should be used:

$$
y_{s} / y_{1}=4 F r^{0.33} K_{1} K_{2} / 0.55,
$$

where $y_{1}$ is defined as the depth of flow (in feet) at the abutment prior to scour (either in the main channel or in the floodplain, depending on the location of the abutment) and all other variables are as defined for the Froehlich equation. The Hire equation rather than the Froehlich equation was used for 10 of the 100 abutments in this study (italicized in table 4).

Although HEC-RAS includes an abutment-scour component using the Froehlich equation for its calculations, Parr and Smith (2000) indicate that the scour portion of HEC-RAS 2.2 should be used with a great deal of caution. Although HEC-RAS 3.1.3 is currently (2008) the active version, this evaluation may still be valid.

\section{Sturm Method}

The Sturm method (Richardson and Davis, 2001) relies on a discharge distribution factor $(M)$ in the approach cross section rather than the measure of the abutment length $(L)$ to predict total scour at the abutment (including contraction scour). Sturm developed a series of equations for various hydraulic conditions, including clear-water scour, live-bed scour with abutments set back from the main channel, and live-bed scour with abutments at the bankline. The equation for clear-water scour is:

$$
\frac{d_{s}}{y_{f 0}}=8.14 K_{s t}\left(\frac{q_{f 1}}{M V_{c} y_{f 0}}-0.4\right)+1,
$$

where

$d_{s} \quad$ is the depth of total scour (abutment plus contraction) at the abutment (feet below the streambed surface),

$y_{f 0} \quad$ is the average depth of flow on the approach floodplain without the bridge in the model (feet),

$K_{s t} \quad$ is Sturm's abutment shape correction factor (for vertical wall abutments $K_{s t}=1$ ),

$q_{f 1} \quad$ is the unit flow rate blocked by the embankment in the approach (square feet per second) (equal to the velocity blocked by the embankment $\left(V_{f 1}\right)$ multiplied by the depth blocked by the embankment $\left(y_{f 1}\right)$ ),

$V_{c} \quad$ is the critical velocity of the median bed material on the approach floodplain without the bridge in the model (feet per second), and

$M \quad$ is the discharge distribution factor defined as $\left(Q_{1 / 2 c h}+Q_{f p}-Q_{b f}\right) /\left(Q_{1 / 2 c h}+Q_{f p}\right)$

where

$Q_{1 / 2 c h} \quad$ is the flow from the center to the edge of the main channel in the approach (cubic feet per second),

$Q_{f p} \quad$ is the floodplain flow in the approach (cubic feet per second), and

$Q_{b f} \quad$ is the discharge blocked by the embankment in the approach (cubic feet per second).

In cases where live-bed scour is present with abutments that are set back from the main channel, $V_{f 1}$ is set equal to the critical velocity of the flow blocked by the embankment $\left(\mathrm{V}_{f l c}\right), q_{f 1}$ is recalculated and the equation for clear-water scour listed above is used. Where live-bed scour is present and the abutments are at the bankline, adjustments are made to the coefficients, the unit flow rate, and the critical velocity (see Richardson and Davis (2001) for full details).

Note that in the Sturm equation $d_{s}$ is the depth of total scour (abutment scour plus contraction scour) at the abutment; therefore, contraction scour using the Laursen equation in HEC-18 (Richardson and Davis, 2001) was subtracted to 
Table 4. Predicted and observed maximum abutment-scour depths at 50 bridges in Maine.

[GPR, ground-penetrating radar; ft, feet; --, no GPR measurements made; italicized values estimated with Hire equation]

\begin{tabular}{|c|c|c|c|c|c|c|c|}
\hline \multirow{2}{*}{$\begin{array}{c}\text { Site } \\
\text { identi- } \\
\text { fier }\end{array}$} & \multirow{2}{*}{ Stream name and town } & \multicolumn{2}{|c|}{$\begin{array}{l}\text { Visible observed scour } \\
\text { (ft) }\end{array}$} & \multicolumn{2}{|c|}{$\begin{array}{c}\text { Scour measured with GPR } \\
(\mathrm{ft})\end{array}$} & \multicolumn{2}{|c|}{$\begin{array}{c}\text { Total observed scour } \\
\text { (ft) }\end{array}$} \\
\hline & & $\begin{array}{c}\text { Left } \\
\text { abutment }\end{array}$ & $\begin{array}{c}\text { Right } \\
\text { abutment }\end{array}$ & $\begin{array}{c}\text { Left } \\
\text { abutment }\end{array}$ & $\begin{array}{c}\text { Right } \\
\text { abutment }\end{array}$ & $\begin{array}{c}\text { Left } \\
\text { abutment }\end{array}$ & $\begin{array}{c}\text { Right } \\
\text { abutment }\end{array}$ \\
\hline 1 & Ogunquit River at Ogunquit & 1.2 & 0 & -- & -- & 1.2 & 0.0 \\
\hline 2 & Webhannet River at Wells & 0 & 2.8 & -- & -- & 0.0 & 2.8 \\
\hline 3 & Merriland River at Wells & 0 & 0.8 & -- & -- & 0.0 & 0.8 \\
\hline 4 & Littlefield River at Alfred & 0 & 0 & -- & -- & 0.0 & 0.0 \\
\hline 5 & Little River at Gorham & 2.5 & 0 & 3 & 0 & 5.5 & 0.0 \\
\hline 6 & Quaker Brook at East Baldwin & 0 & 0 & -- & -- & 0.0 & 0.0 \\
\hline 7 & Pleasant River at Windham & 0 & 0 & -- & -- & 0.0 & 0.0 \\
\hline 8 & Pleasant River at Windham & 2 & 0 & 3 & 0 & 5.0 & 0.0 \\
\hline 9 & Breakneck Brook at Baldwin & 0 & 0.5 & -- & -- & 0.0 & 0.5 \\
\hline 10 & Royal River at North Yarmouth & 0 & 0 & -- & -- & 0.0 & 0.0 \\
\hline 11 & Hancock Brook at Hiram & 0 & 0 & -- & -- & 0.0 & 0.0 \\
\hline 12 & Tenmile River at Brownfield & 0 & 0.7 & -- & -- & 0.0 & 0.7 \\
\hline 13 & Gillespie Brook at Bowdoin & 2.8 & 1.8 & 4 & 0 & 6.8 & 1.8 \\
\hline 14 & Medomak River at Waldoboro & 2.5 & 0 & 3 & -- & 5.5 & 0.0 \\
\hline 15 & Little Cold River at Stow & 1.4 & 0 & 0 & 0 & 1.4 & 0.0 \\
\hline 16 & Meadow Brook at Norway & 0 & 2.3 & -- & -- & 0.0 & 2.3 \\
\hline 17 & Crooked River at Albany Township (1) & 0 & 0 & -- & -- & 0.0 & 0.0 \\
\hline 18 & Crooked River at Albany Township (2) & 0 & 0 & -- & -- & 0.0 & 0.0 \\
\hline 19 & West Branch Sheepscot River at Windsor & 1.5 & 1.4 & -- & 0 & 1.5 & 1.4 \\
\hline 20 & Saint George River at Appleton & 0 & 3 & 0 & 0 & 0.0 & 3.0 \\
\hline 21 & Stony Brook at Batchelders Grant & 0.5 & 0 & -- & -- & 0.5 & 0.0 \\
\hline 22 & Lovejoy Pond Outlet Stream at Wayne & 0 & 1.4 & -- & -- & 0.0 & 1.4 \\
\hline 23 & Whites Brook at Gilead & 1.7 & 0 & -- & -- & 1.7 & 0.0 \\
\hline 24 & Concord Brook at Rumford & 0 & 0 & -- & -- & 0.0 & 0.0 \\
\hline 25 & Stony Brook at Hanover & 0 & 2.7 & -- & -- & 0.0 & 2.7 \\
\hline 26 & Tunk Stream at Steuben & 1.5 & 0 & 0 & -- & 1.5 & 0.0 \\
\hline 27 & Wilson Stream at Farmington & 0 & 0 & -- & -- & 0.0 & 0.0 \\
\hline 28 & Stony Brook at Andover & 0 & 1 & -- & -- & 0.0 & 1.0 \\
\hline 29 & Webb Brook at Waltham & 0.4 & 0 & -- & -- & 0.4 & 0.0 \\
\hline 30 & Tannery Brook at Waltham & 0 & 2.2 & -- & 0 & 0.0 & 2.2 \\
\hline 31 & West Brook at Weld & 2 & 1.9 & 0 & 0 & 2.0 & 1.9 \\
\hline 32 & West Branch Souadabscook River at Hampden & 0 & 2.2 & -- & -- & 0.0 & 2.2 \\
\hline 33 & West Branch Wesserunsett Stream at Skowhegan & 0 & 2.7 & -- & 0 & 0.0 & 2.7 \\
\hline 34 & East Branch Wessurunsett Stream at Athens & 0 & 0 & -- & -- & 0.0 & 0.0 \\
\hline 35 & West Branch Carrabassett River at Kingfield & 1.2 & 2.5 & -- & -- & 1.2 & 2.5 \\
\hline 36 & Paul Brook at Corinth & 0.9 & 0.9 & 0.5 & 0.5 & 1.4 & 1.4 \\
\hline 37 & Pushaw Stream at Hudson & 0 & 2.5 & -- & 0.5 & 0.0 & 3.0 \\
\hline 38 & Sunkhaze Stream at Greenfield & 1.1 & 0 & -- & -- & 1.1 & 0.0 \\
\hline 39 & West Branch Dead Stream at Bradford & 0 & 0 & -- & -- & 0.0 & 0.0 \\
\hline 40 & Middle Branch Dead Stream at Bradford & 0 & 0 & -- & -- & 0.0 & 0.0 \\
\hline 41 & Black Stream at Dover-Foxcroft & 0 & 1 & -- & -- & 0.0 & 1.0 \\
\hline 42 & Alder Stream at Atkinson & 1.2 & 0 & 1 & -- & 2.2 & 0.0 \\
\hline 43 & Macwahoc Stream at Macwahoc & 0 & 0 & -- & -- & 0.0 & 0.0 \\
\hline 44 & South Branch Meduxnekeag River at Cary Plantation & 0 & 0.9 & -- & -- & 0.0 & 0.9 \\
\hline 45 & Dunn Brook at New Limerick & 0 & 0 & -- & -- & 0.0 & 0.0 \\
\hline 46 & Moose Brook at Houlton & 0 & 0 & -- & -- & 0.0 & 0.0 \\
\hline 47 & Umcolcus Stream at Oxbow Plantation & 0 & 1 & -- & -- & 0.0 & 1.0 \\
\hline 48 & Prestile Stream at Blaine & 1 & 0.8 & -- & -- & 1.0 & 0.8 \\
\hline 49 & Salmon Brook at Washburn & 0.6 & 5.2 & -- & 0 & 0.6 & 5.2 \\
\hline 50 & Little Madawaska Stream at Stockholm & 0 & 0.2 & -- & -- & 0.0 & 0.2 \\
\hline
\end{tabular}




\begin{tabular}{|c|c|c|c|c|c|c|c|c|}
\hline \multirow{2}{*}{$\begin{array}{c}\text { Laursen's } \\
\text { contraction scour } \\
\text { (ft) }\end{array}$} & \multicolumn{2}{|c|}{$\begin{array}{l}\text { Scour predicted by } \\
\text { Froehlich/Hire method } \\
\text { (ft) }\end{array}$} & \multicolumn{2}{|c|}{$\begin{array}{l}\text { Scour predicted by } \\
\text { Sturm method } \\
\text { (ft) }\end{array}$} & \multicolumn{2}{|c|}{$\begin{array}{l}\text { Scour predicted by } \\
\text { Maryland method } \\
\text { (ft) }\end{array}$} & \multicolumn{2}{|c|}{$\begin{array}{l}\text { Scour predicted by } \\
\text { Melville method } \\
\text { (ft) }\end{array}$} \\
\hline & $\begin{array}{c}\text { Left } \\
\text { abutment }\end{array}$ & $\begin{array}{c}\text { Right } \\
\text { abutment }\end{array}$ & $\begin{array}{c}\text { Left } \\
\text { abutment }\end{array}$ & $\begin{array}{c}\text { Right } \\
\text { abutment }\end{array}$ & $\begin{array}{c}\text { Left } \\
\text { abutment }\end{array}$ & $\begin{array}{c}\text { Right } \\
\text { abutment }\end{array}$ & $\begin{array}{c}\text { Left } \\
\text { abutment }\end{array}$ & $\begin{array}{c}\text { Right } \\
\text { abutment }\end{array}$ \\
\hline-1.7 & 10.7 & 10.0 & 12.2 & 11.5 & 1.0 & 0.9 & 0.0 & 0.0 \\
\hline-0.5 & 3.2 & 1.7 & 2.6 & 0.2 & 1.2 & 1.2 & 1.1 & 0.4 \\
\hline-0.8 & 4.2 & 3.6 & 3.0 & 2.4 & 3.5 & 3.3 & 1.6 & 1.3 \\
\hline 17.8 & 11.9 & 15.0 & 11.2 & 4.8 & 10.0 & 10.0 & 0.0 & 0.0 \\
\hline-6.6 & 15.5 & 22.7 & 16.6 & 2.9 & 4.5 & 4.2 & 5.9 & 21.3 \\
\hline 22.7 & 26.1 & 26.1 & -5.2 & -17.7 & -0.7 & -0.7 & 0.0 & 0.0 \\
\hline 16.8 & 15.6 & 16.0 & -15.9 & -12.7 & 4.2 & 4.4 & 14.7 & 18.1 \\
\hline 2.6 & 14.4 & 17.7 & 5.0 & 10.6 & 5.8 & 6.1 & 4.2 & 4.5 \\
\hline-1.4 & 16.1 & 4.9 & 7.6 & 3.5 & 1.6 & 1.6 & 5.0 & 1.8 \\
\hline 2.6 & 13.9 & 9.6 & 20.1 & 22.4 & 200.3 & 166.4 & 18.1 & 10.9 \\
\hline-1.6 & 1.8 & 13.2 & 0.8 & 3.1 & 2.7 & 3.1 & 0.0 & 7.3 \\
\hline-0.6 & 12.7 & 11.0 & 7.9 & 8.3 & 8.5 & 8.9 & 7.1 & 6.1 \\
\hline 4.5 & 8.4 & 7.7 & 6.7 & 7.4 & 3.8 & 5.0 & 10.2 & 9.1 \\
\hline-1.1 & 1.6 & 0.5 & 15.1 & 15.1 & 5.9 & 5.5 & 2.3 & 0.4 \\
\hline 5.5 & 6.0 & 9.2 & 12.7 & 24.6 & 27.9 & 38.4 & 3.6 & 4.5 \\
\hline-0.9 & 7.5 & 22.0 & 2.9 & 6.7 & 0.9 & 0.9 & 0.7 & 1.6 \\
\hline 1.2 & 10.7 & 10.2 & 18.7 & 14.2 & 13.6 & 15.7 & 3.8 & 4.7 \\
\hline 0.6 & 5.6 & 33.2 & 0.7 & 11.4 & 6.8 & 8.1 & 5.8 & 12.1 \\
\hline 3.4 & 23.8 & 23.8 & -3.4 & 1.5 & 2.4 & 2.4 & 0.0 & 0.0 \\
\hline-4.6 & 18.5 & 15.7 & 50.9 & 8.8 & 1.0 & 1.3 & 0.0 & 0.0 \\
\hline 0.4 & 6.4 & 11.3 & 4.7 & 5.4 & 10.2 & 10.7 & 2.0 & 7.3 \\
\hline-3.0 & 10.1 & 15.0 & 6.9 & 8.2 & 1.3 & 0.9 & 3.8 & 9.0 \\
\hline 2.1 & 8.5 & 16.6 & 3.0 & 7.3 & 1.7 & 2.1 & 4.1 & 6.3 \\
\hline 0.6 & 7.1 & 5.8 & 10.0 & 6.9 & 50.4 & 67.2 & 1.4 & 8.5 \\
\hline-0.7 & 7.4 & 21.5 & 2.6 & 5.3 & 0.9 & 1.0 & 1.9 & 4.8 \\
\hline 3.8 & 9.1 & 8.6 & 1.2 & 2.4 & 3.4 & 4.6 & 6.9 & 7.0 \\
\hline-3.8 & 19.3 & 14.5 & 19.8 & 9.7 & 6.7 & 6.3 & 4.7 & 3.5 \\
\hline-1.3 & 1.1 & 4.9 & -1.0 & -0.6 & 5.8 & 8.8 & 0.0 & 0.7 \\
\hline 1.5 & 10.5 & 8.8 & 10.5 & 7.4 & 3.9 & 3.2 & 0.0 & 0.0 \\
\hline-0.1 & 15.8 & 7.1 & 25.8 & 4.9 & 2.0 & 1.6 & 4.8 & 1.4 \\
\hline 4.3 & 11.3 & 12.5 & 8.4 & 5.4 & 8.3 & 8.5 & 19.5 & 18.5 \\
\hline-0.2 & 5.2 & 12.7 & -0.4 & 4.7 & 19.6 & 23.2 & 1.1 & 1.5 \\
\hline-0.0 & 12.6 & 12.9 & 13.5 & 11.1 & 11.7 & 13.5 & 5.3 & 5.6 \\
\hline-3.2 & 0.0 & 4.6 & -2.3 & 2.3 & 10.2 & 11.6 & 0.0 & 6.7 \\
\hline 2.7 & 0.0 & 0.0 & 13.9 & -7.5 & 33.7 & 38.5 & 0.0 & 0.0 \\
\hline-0.9 & 8.5 & 8.2 & 3.1 & 5.0 & 3.2 & 3.4 & 1.6 & 1.7 \\
\hline-0.7 & 13.4 & 14.8 & 11.5 & 12.0 & 4.3 & 5.0 & 2.2 & 3.2 \\
\hline-0.3 & 9.3 & 9.5 & 12.5 & 12.7 & 5.3 & 4.6 & 1.8 & 1.9 \\
\hline 1.8 & 6.9 & 5.9 & 7.4 & 8.9 & 7.9 & 8.5 & 0.0 & 0.0 \\
\hline 0.6 & 9.0 & 3.6 & 7.5 & 1.7 & 6.2 & 5.2 & 3.8 & 1.6 \\
\hline-0.5 & 5.9 & 7.2 & 6.4 & 6.1 & 1.6 & 1.8 & 0.9 & 1.4 \\
\hline-0.2 & 7.3 & 7.5 & 0.2 & 0.2 & 4.2 & 4.2 & 3.8 & 4.3 \\
\hline 1.1 & 11.0 & 10.5 & 15.6 & 10.9 & 12.0 & 11.4 & 4.6 & 4.8 \\
\hline-1.0 & 5.9 & 10.3 & 2.1 & 6.7 & 6.0 & 4.9 & 5.8 & 2.9 \\
\hline 1.0 & 14.4 & 7.6 & 6.0 & 7.0 & 2.7 & 2.1 & 4.7 & 2.7 \\
\hline-0.7 & 9.5 & 5.0 & 7.6 & 2.0 & 1.6 & 1.4 & 4.6 & 1.3 \\
\hline-0.3 & 14.4 & 15.9 & 5.8 & 6.0 & 2.7 & 3.2 & 2.2 & 3.5 \\
\hline 1.7 & 16.7 & 16.8 & 13.7 & 13.5 & 5.5 & 5.1 & 5.6 & 4.9 \\
\hline 1.1 & 17.1 & 14.5 & 13.3 & 11.3 & 16.1 & 14.3 & 1.3 & 11.3 \\
\hline-7.6 & 22.6 & 21.4 & 5.9 & 20.0 & 1.8 & 2.5 & 10.0 & 8.3 \\
\hline
\end{tabular}


evaluate abutment scour independently. If the average depth of flow on the approach floodplain without the bridge in the model $\left(y_{f 0}\right)$, was equal to zero, the equation becomes unsolvable; in these cases, therefore, $d_{s}$ was set to zero.

\section{Maryland Method}

The Maryland method as given in HEC-18 (Richardson and Davis, 2001) applies coefficients for velocity and flow in the contracted bridge cross section to contraction-scour equations to predict abutment scour (combined local abutment scour and contraction scour). Equations are given for clear-water scour and live-bed scour. Maryland's clear-water abutment-scour equation is:

$$
y_{2 a}=k_{f}\left(k_{v}\right)^{0.857} y_{2 c},
$$

where

$$
y_{2 a} \quad \text { is the total depth of flow at the abutment }
$$
measured from the water surface to the bottom of the scour hole (feet);

$y_{2 c} \quad$ is the clear-water contraction scour depth at critical velocity $\left(q_{2} / V_{c}\right.$ for this report) (feet), where $V_{c}$ is the critical velocity above which the median grain size will be transported (feet per second);

$k_{f}=0.1+4.5 F_{1}$ (with limiting values of 1.0 and 3.3),

where

$$
F_{1}=V_{1} /\left(g y_{1}\right)^{0.5},
$$

where

$$
\begin{gathered}
V_{1} \quad \begin{array}{l}
\text { is the average approach flow velocity in } \\
\text { the main channel or in the floodplain } \\
\text { depending on the location of the }
\end{array} \\
\text { abutment (feet); } \\
g \quad \text { is the force of gravity, } 32.2 \mathrm{ft} / \mathrm{s}^{2} \text {; and } \\
y_{1} \quad \text { is the average approach flow depth in } \\
\text { the main channel or in the floodplain } \\
\text { depending on the location of the } \\
\text { abutment (feet); }
\end{gathered}
$$

$k_{v}=0.8\left(q_{1} / q_{2}\right)^{1.5}+1$ (with limiting values of 1.0 and 1.8),

where

$$
\begin{aligned}
& q_{1} \quad \text { is the flow rate per unit width in the approach } \\
& \text { section (square feet per second); and } \\
& q_{2} \quad \text { is the flow rate per unit width in the } \\
& \text { contracted section (square feet per second). }
\end{aligned}
$$

Velocities, and therefore, unit flow rates under the bridges will vary depending on whether the bridge has short, intermediate, or long setbacks (see Richardson and Davis, 2001 for details).
Maryland's live-bed abutment scour equation is

$$
y_{2 a} / y_{1}=k_{f}\left[k_{v} q_{2} / q_{1}\right]^{k 2} \text {, }
$$

where

$$
\begin{aligned}
& k_{f}=0.35+3.2 F_{1}(\text { with limiting values of } 1.0 \text { and } 3.3), \\
& k_{2}=0.11\left(\tau_{c} / \tau_{1}+0.4\right)^{2.2}+0.623 \text { (with limiting values of } \\
& 0.637 \text { and } 0.857),
\end{aligned}
$$

where

$$
\begin{array}{cl}
\tau_{c} \quad= & \text { critical shear stress of the bed material } \\
& \text { (pounds per square foot) }, \\
\tau_{1} \quad & \text { shear stress at approach section (pounds per } \\
& \text { square foot) },
\end{array}
$$

and the other variables are as described in Maryland's clearwater equation above.

The initial flow depth at the abutment before scour $\left(y_{0}\right)$ must be subtracted from $\mathrm{y}_{2 a}$, computed with either Maryland's clear-water or live-bed equation, in order to obtain a scour depth from the bed $y_{s a} ; y_{s a}$ is then multiplied by an abutment shape factor $\left(K_{t}\right)$ and a coefficient for the skew angle. For this study, $y_{0}$ was estimated as the depth in the approach cross section upstream from the abutment because $y_{0}$ at the abutment before scour is unknown. Adding a factor of safety to the Maryland equations is optional and was not done for this report.

The clear-water contraction scour depth from the water surface $\left(y_{2 c}\right)$, computed with the Maryland method, can be estimated as $q_{2} / V_{c}$ or obtained from Laursen's clear-water average contraction scour depth from the water surface $\left(y_{2}\right)$. In this study $q_{2} / V_{c}$ was used because it is the primary method specified in the Maryland method (Richardson and Davis, 2001). Contraction scour depth from the bed was then subtracted from the total scour depth from the bed using Laursen's estimated contraction scour from the bed $\left(y_{s}\right)$ in order to be consistent across methods.

\section{Melville Method}

The abutment-scour depth as given by Melville (1997) is:

$$
y_{s}=K_{y L} K_{I} K_{d} K_{s} K_{\theta} K_{G},
$$

where

$y_{s} \quad$ is the total abutment-scour depth at the abutment (in feet from the bed),

$K \quad$ represents empirical expressions accounting for the various influences on scour depth,

$K_{y L} \quad$ depends on depth of flow and abutment length,

$K_{I} \quad$ depends on flow intensity,

$K_{d} \quad$ depends on sediment size, 
$K_{s} \quad$ depends on abutment shape,

$K_{\theta}$ depends on abutment alignment, and

$K_{G} \quad$ depends on channel geometry.

The $K$ factors were developed by fitting envelope curves to abutment-scour data (see Melville (1997) for details).

\section{Envelope Curves}

Individual variables collected or computed for this study that have the potential to influence abutment-scour depths were tested to determine whether an envelope curve (to assess the upper range of observed scour depths for a given variable) could be helpful in predicting maximum abutment scour. Variables tested included the median sediment size; the abutment skew to flow; the length of flow blocked by the embankment; the amount of flow contraction caused by the bridge (the contraction ratio); and main channel and floodplain depths, velocities, and discharges in the approach.

\section{Observed and Predicted Abutment- Scour Depths}

The total maximum observed abutment scour and its components for 50 bridges in Maine are listed in table 4. Abutment scour was observed at 35 of the 50 bridge sites in this study. Seven of those 35 sites had scour holes at both the left abutment and the right abutment, 11 had abutment scour only on the left abutment, and 17 had scour only on the right abutment. Fifteen sites had no observable scour. Maximum scour (including scour measured with GPR - see "GroundPenetrating Radar in Scour Holes" section) ranged from $0 \mathrm{ft}$ to a maximum of $6.8 \mathrm{ft}$ (table 4). Maximum abutment scour exceeded $2.5 \mathrm{ft}$ at 10 sites. The average maximum observed abutment scour was less than $1 \mathrm{ft}$. Fourteen of the 22 GPR measurements detected no additional scour, and the remaining 8 measurements detected from 0.5 to $4.0 \mathrm{ft}$ of additional scour (table 4). As described earlier, infilled scour holes may not be detectable by GPR in some situations.

Predicted scour at individual sites using the Froehlich/ Hire, Sturm, Maryland, and Melville methods are given in table 4; average, maximum, and minimum values of scour predicted with each of the four methods; the percent of values that are overpredicted and underpredicted; and the average and maximum overpredictions and underpredictions are given in table 5. The Froehlich/Hire and Maryland methods yielded the highest average predicted scour, approximately $11 \mathrm{ft}$. The average predicted scour for the Melville method, $4.3 \mathrm{ft}$, is closest to, but still $3.5 \mathrm{ft}$ higher than, the observed average scour of $0.8 \mathrm{ft}$. The equations frequently overpredicted scour by an order of magnitude and occasionally by two orders of magnitude. Underpredictions were less common than overpredictions, but occurred in all of the methods tested at
4 to 14 percent of the sites (figs. 4-7). The Sturm method had the largest average underpredictions and the Maryland and Melville methods had the smallest average underpredictions. The Sturm method yielded the minimum predicted value of any of the methods, $-17.7 \mathrm{ft}$ (fig. 5), and the Maryland method yielded the maximum predicted value of any of the methods, $200.3 \mathrm{ft}$ (fig. 6). These extreme values are not physically plausible.

Table 5. Predicted maximum abutment-scour depth compared to observed maximum abutment-scour depth for 50 bridges in Maine.

[ft, feet; NA, not applicable]

\begin{tabular}{|c|c|c|c|}
\hline \multirow[b]{2}{*}{ Method } & \multicolumn{3}{|c|}{ Observed scour (ft) } \\
\hline & Average & Minimum & Maximum \\
\hline \multirow{2}{*}{ Measured in field } & 0.8 & 0.0 & 6.8 \\
\hline & \multicolumn{3}{|c|}{ Predicted scour (ft) } \\
\hline Method & Average & Minimum & Maximum \\
\hline Froehlich/Hire method & 11.1 & 0.0 & 33.2 \\
\hline Sturm method & 7.3 & -17.7 & 50.9 \\
\hline Maryland method & 11.2 & -0.7 & 200.3 \\
\hline \multirow[t]{3}{*}{ Melville method } & 4.3 & 0.0 & 21.3 \\
\hline & \multicolumn{3}{|c|}{$\begin{array}{l}\text { Comparison of observed } \\
\text { and predicted scour }\end{array}$} \\
\hline & \multicolumn{3}{|c|}{ Overpredictions } \\
\hline Method & Percent & Average (ft) & Maximum (ft) \\
\hline Froehlich/Hire method & 96 & 10.8 & 33.2 \\
\hline Sturm method & 86 & 8.4 & 50.9 \\
\hline Maryland method & 89 & 11.8 & 200.3 \\
\hline \multirow[t]{2}{*}{ Melville method } & 86 & 4.3 & 21.3 \\
\hline & \multicolumn{3}{|c|}{ Underpredictions } \\
\hline Method & Percent & Average (ft) & Maximum (ft) \\
\hline Froehlich/Hire method & 4 & 2.2 & 3.9 \\
\hline Sturm method & 14 & 5.5 & 17.7 \\
\hline Maryland method & 11 & 1.2 & 3.0 \\
\hline Melville method & 14 & 1.4 & 3.2 \\
\hline
\end{tabular}




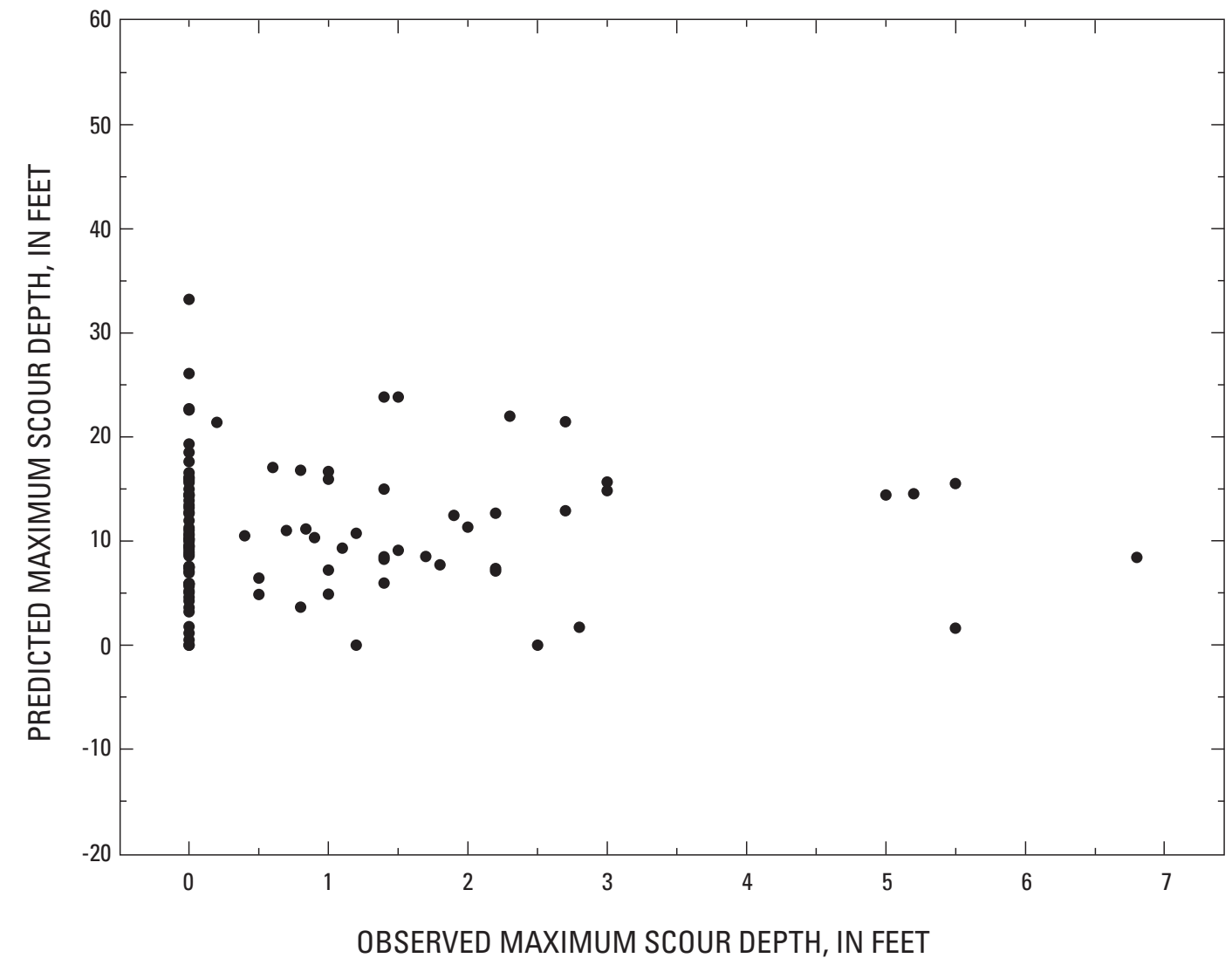

Figure 4. Relation of observed maximum abutment-scour depth to predicted maximum abutment-scour depth computed by the Froehlich/Hire method for 50 bridges in Maine.

Figure 5. Relation of observed maximum abutment-scour depths to predicted maximum abutment-scour depths computed by the Sturm method for 50 bridges in Maine.

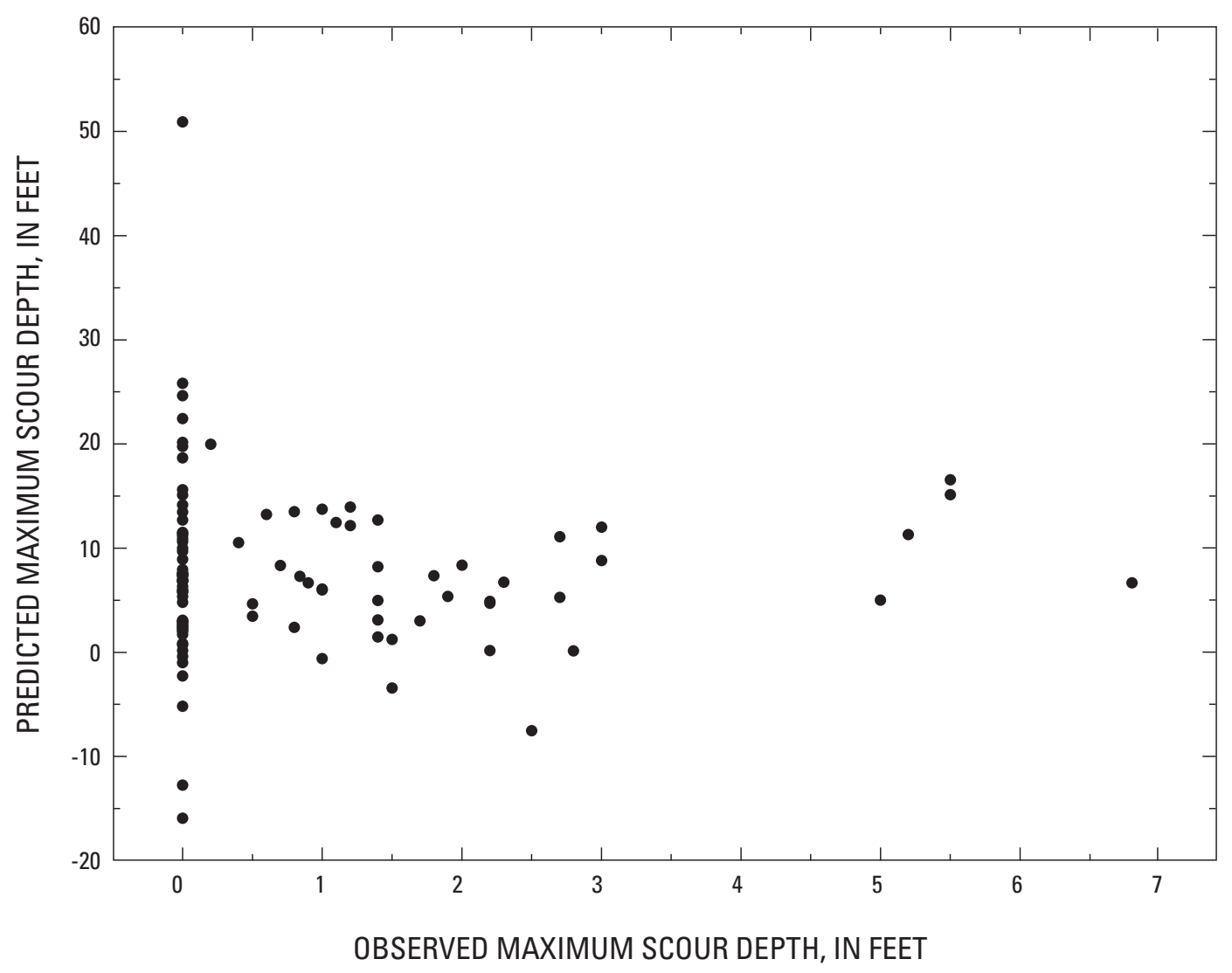




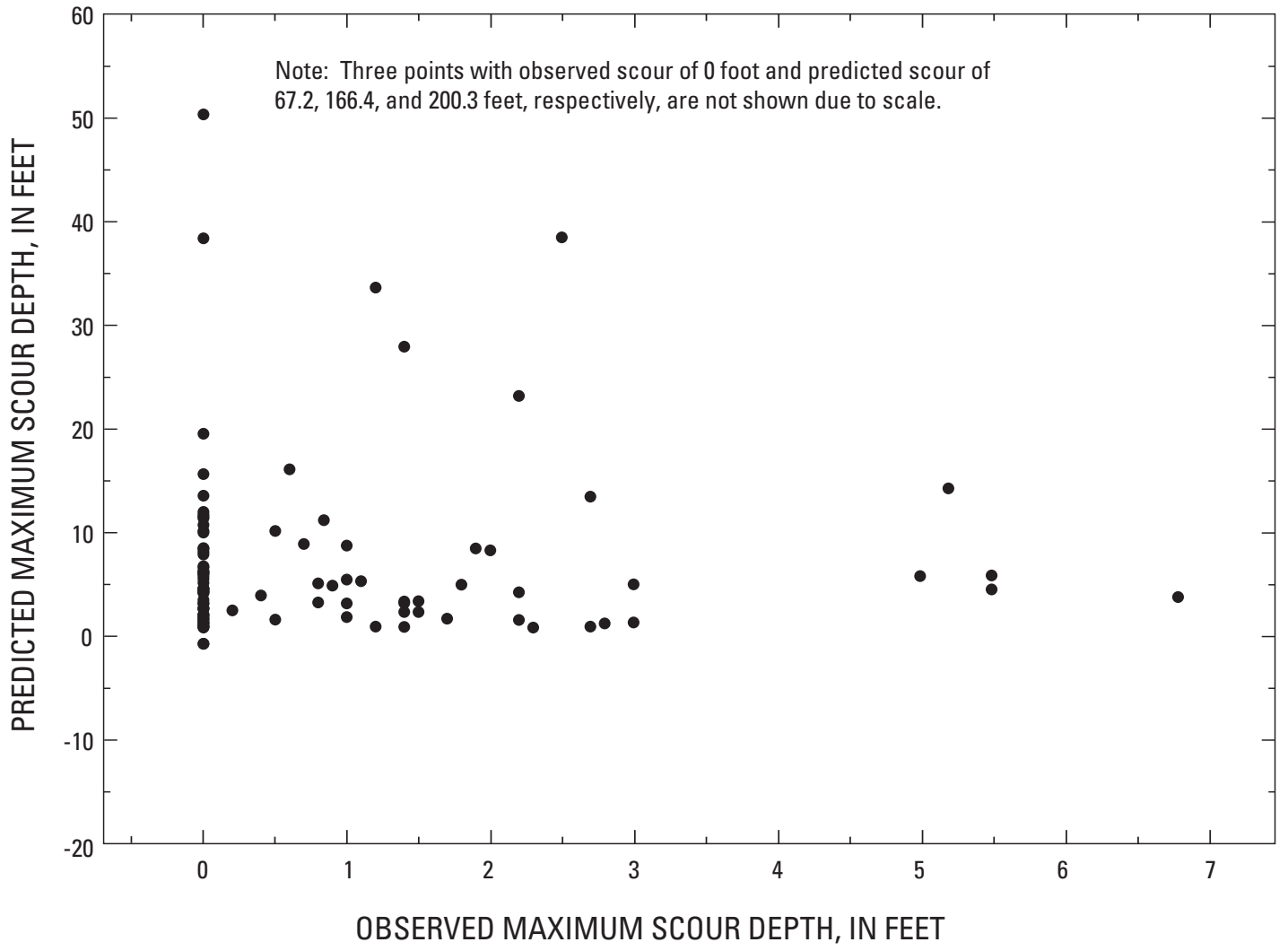

Figure 6. Relation of observed maximum abutment-scour depths to predicted maximum abutmentscour depths computed by the Maryland method for 50 bridges in Maine.
Figure 7. Relation of observed maximum abutment-scour depths to predicted maximum abutmentscour depths computed by the Melville method for 50 bridges in Maine.

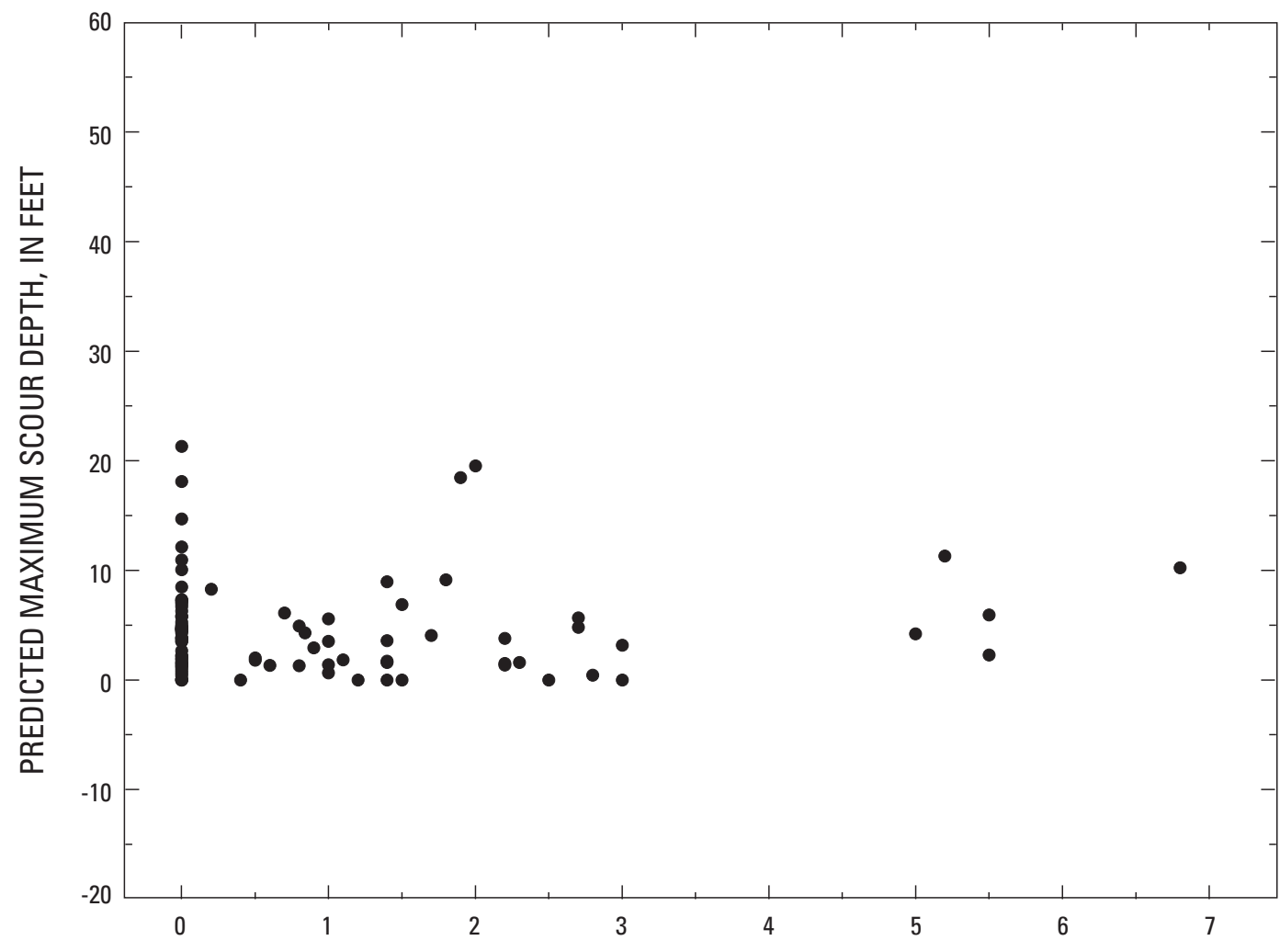

OBSERVED MAXIMUM SCOUR DEPTH, IN FEET 
Negative scour was computed at some sites using the Sturm and Maryland methods. No cases of negative scour were documented in the development of the equations for any of the methods. Although negative scour could be interpreted as sediment accumulation, it could also be interpreted as outside the range of conditions for which the equations were designed and an indication that the equations are not appropriate for the given conditions. Negative results were not censored in the comparison between observed and predicted scour even though it is unlikely that negative scour results have a physical meaning that was evaluated in the development of this equation.

In the 50 bridges examined in this study, no correlation was found between maximum observed abutment scour and maximum predicted abutment scour from the four different prediction methods (correlations had $r$ values of less than 0.1 in all cases) (table 6). The absence of a relation between observed scour and scour predicted with the Froehlich/Hire, Sturm, Maryland, and Melville methods is shown in figures 4 through 7, respectively. Furthermore, none of the individual variables calculated in this study to create envelope equations showed any correlation with maximum observed abutment scour depths; for example, the lack of relation between the length of active flow blocked by the embankment $\left(L^{\prime}\right)$ and observed abutment scour is seen in figure 8 .

Correlation coefficients between observed and predicted scour ranged from -0.09 with the Maryland method to 0.08 with the Melville method (table 6). The average predicted scour from the Melville method, $4.3 \mathrm{ft}$, is the closest to the observed average scour of $0.8 \mathrm{ft}$; however, no correlation was found between scour predicted with the Melville method and the observed scour (fig. 7). Previous studies have reached similar conclusions to those in this study. Predicted abutment scour from the Froehlich/Hire, Sturm, and Maryland methods compared poorly to observed scour at 144 bridges in South Carolina (Benedict and others, 2006). Wagner and others (2006) concluded that "simple equations based on simple experiments are not able to account for the complexities of typical field conditions" after observing scour at 12 sites in
South Dakota, Minnesota, and Montana, and determining that the Froehlich, Hire and Sturm equations were unreliable. Abutment scour at small bridges in Maine with vertical abutments and wingwalls is not related to any expected variables. Abutment scour may be caused by variables that were not tested, such as major meanders or ice jams, or may be the result of a complex interaction of variables.

It is important to note that the methods tested include the selection of scour-prediction variables from one-dimensional hydraulic models as opposed to the collection of hydraulic data in the field. Model results are estimations and can be a source of inaccuracies. Although flow conditions that created scour at individual bridges are estimations, the large number of older bridges ( 50 bridges with a median age of 66 years) evaluated in the field most likely provided a representative sample of the range of maximum abutment scour that typically occurs in Maine at bridges of the type considered in this study. In no case did observed scour exceed $7 \mathrm{ft}$. The range of observed abutment scour matches the range observed by bridge inspectors at MaineDOT (C. Edwards, Maine Department of Transportation, oral commun., 2007), and was also supported by MaineDOT inspection dive reports from 1996 through 2007.

Table 6. Correlations between predicted and observed maximum abutment-scour depths for 50 bridges in Maine.

\begin{tabular}{lc}
\hline Method of predicting scour & Correlation coefficient \\
\hline Froehlich/Hire method & 0.00 \\
Sturm method & 0.01 \\
Maryland method & -0.09 \\
Melville method & 0.08 \\
\hline
\end{tabular}




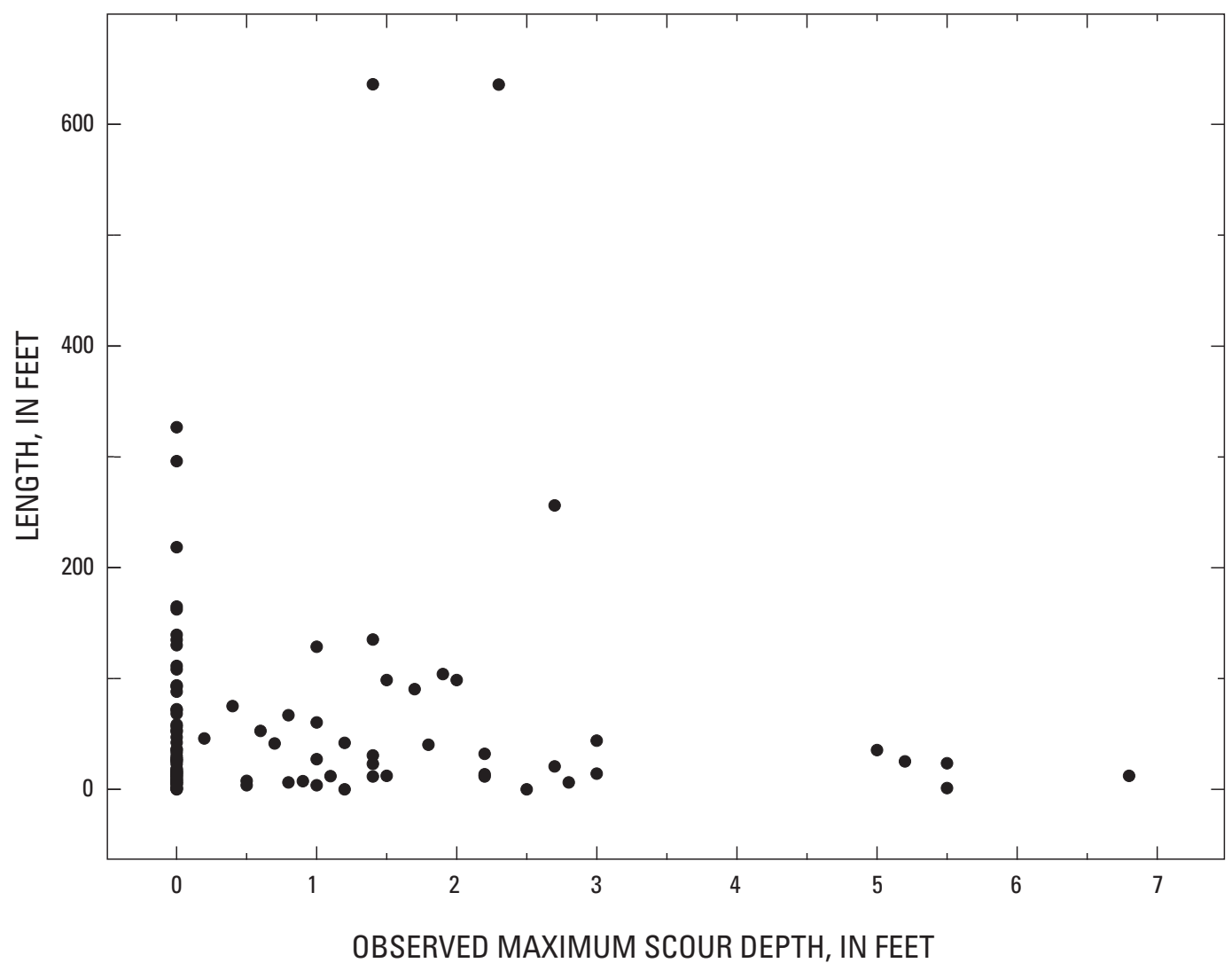

Figure 8. Relation of observed maximum abutment-scour depth to the length of the active flow blocked by the bridge embankment at 50 bridges in Maine. 


\section{Summary and Conclusions}

The U.S. Geological Survey (USGS) conducted a study in cooperation with Maine Department of Transportation (MaineDOT) in which 100 values of maximum abutment scour computed with four prediction methods were compared with maximum observed abutment scour measured at these same sites in the field. Methods tested included the Froehlich/ Hire method, the Sturm method, the Maryland Department of Transportation method, and the Melville method. All of the equations from these methods except the Hire equation were developed in the laboratory and have not been tested extensively with field data. The fifth method investigated relations between individual bridge site variables and observed scour in an attempt to create envelope equations. No correlation existed between scour calculated with any of these five methods and scour observed in the field. Maximum abutment scour observed in the field ranged from 0 to $6.8 \mathrm{ft}$, with an average observed scour of less than $1.0 \mathrm{ft}$. Equations frequently overpredicted scour by an order of magnitude, and in some cases by two orders of magnitude. All equations also underpredicted scour at 4 to 14 percent of sites.

It may be useful for bridge design purposes to estimate maximum abutment scour at Maine bridges using a single value based on the maximum abutment scour observed at bridges in the current study plus a factor of safety. This conclusion is based on the lack of correlation between predicted and observed abutment scour for the methods tested in this study, the large overpredictions of abutment scour, the less frequent underpredictions of abutment scour, and the relatively small maximum observed abutment scour depths measured in the field.

There are limitations, however, to using a single value based on maximum observed abutment scour depth for bridge design because of the data and assumptions used in this study. One limitation is that the data set is finite. Although 100 abutments at 50 older bridges were examined, and anecdotal evidence by MaineDOT bridge engineers supports a maximum abutment scour depth observed in the field of roughly $7 \mathrm{ft}$, maximum abutment scour depth could exceed this amount. If historical scour were so great as to require bridge replacement, the maximum scour amounts at these bridges would not have been taken into account in this study. Also, it is possible that infilled scour holes were missed at some bridges.

To use the maximum observed scour depth for bridge design in Maine at a given site, the site should have hydraulic and site characteristics similar to the sites measured in this study. Comparable bridges would have vertical wall abutments and wingwalls; pass over streams with drainage areas between 4 and $100 \mathrm{mi}^{2}$; and have bridge openings between 15 and $65 \mathrm{ft}$. For example, the conclusions from this study may not apply to bridges with spill-through abutments.

An additional limitation of this study is that the hydrologic and hydraulic conditions that caused the observed scour are estimations based on the age of the bridge, peak- flow regression equations, and HEC-RAS step-backwater models. Although the estimated hydrologic and hydraulic data introduce error into the final values of predicted scour, these errors are likely typical of errors encountered by bridge engineers applying the tested methods. The median bridge age of 66 years and the large sample size gives confidence that the conditions observed were typical of those found at this type of bridge in Maine. Furthermore, the recurrence intervals of peak flows occurring at eight continuous-record streamflow-gaging stations in the same region as a few of the bridges examined in this study were as large or larger than estimated peak-flow recurrence intervals. Because observed peak flows were generally greater than estimated peak flows, abutment-scour prediction methods would be expected to underpredict rather than overpredict observed scour.

\section{References Cited}

American Association of State Highway and Transportation Officials, 2001, Standard specifications for transportation materials and methods of sampling and testing (21st ed.): Washington D.C., American Association of State Highway and Transportation Officials.

Ashmore, P.E., Yuzyk, T.R., and Herrington, Ross, 1988, Bed-material sampling in sand-bed streams: Sediment Survey Section, Water Resources Branch, Inland Waters Directorate, Environment Canada, Report IWD-HQ-WRBSS-88-4, 83 p.

Barkdoll, B.D., Melville, B.W., and Ettema, Robert, 2006, A review of bridge abutment scour countermeasures: Proceedings of the World Water and Environmental Resources Congress, 2006, Omaha, Nebr.

Bedient, P.B., and Huber, W.C., 1988, Hydrology and floodplain analysis: Reading, Mass., Addison-Wesley Publishing Co., $650 \mathrm{p}$.

Benedict, S.T., 2003, Clear-water abutment and contraction scour in the Coastal Plain and Piedmont Provinces of South Carolina, 1996-99: U.S. Geological Survey WaterResources Investigations Report 03-4064, 137 p.

Benedict, S.T., Deshpande, Mikhil, Aziz, N.M., and Conrads, P.A., 2006, Trends of abutment scour prediction equations applied to 144 field sites in South Carolina: U.S. Geological Survey Open-File Report 2003-295, 150 p.

Benson, M.A., and Dalrymple, Tate, 1968, General field and office procedures for indirect discharge measurements: U.S. Geological Survey Techniques of Water-Resources Investigations, book 3, chap. A1, $30 \mathrm{p}$. 
Edwards, T.K., and Glysson, G.D., 1999, Field methods for measurement of fluvial sediment: U.S. Geological Survey Techniques of Water-Resources Investigations, book 3, chap. C2, 89 p.

Hayes, D.C., 1993, Site selection and collection of bridge-scour data in Delaware, Maryland, and Virginia: U.S. Geological Survey Water-Resources Investigations Report 93-4017, 23 p.

Hodgkins, G.A., 1999, Estimating the magnitude of peak flows for streams in Maine for selected recurrence intervals: U.S. Geological Survey Water-Resources Investigations Report 99-4008, 45 p.

Hodgkins, G.A., and Lombard, P.J., 2002, Observed and predicted pier scour in Maine: U.S. Geological Survey Water-Resources Investigations Report 02-4229, 22 p.

International Organization for Standardization, 1977, Liquid flow measurement in open channels-Bed material sampling: ISO 4364:1977(E), 13 p.

Melville, B.W., 1997, Pier and abutment scour: An integrated approach: Journal of Hydraulic Engineering, v. 123, no. 2, p. $125-136$.
Parr, D.A., and Smith, Andrew, 2000, HEC-RAS 2.2 for backwater and scour analysis-Phase one, Final report K-TRAN research project KU-00-9 (KAN21430), University of Kansas, September 2000, 72 p.

Richardson, E.V., and Davis, S.R., 2001, Evaluating scour at bridges, (4th ed.): Federal Highway Administration Hydraulic Engineering Circular (HEC) 18, Publication FHWA-NHI 01-001, $378 \mathrm{p}$.

U.S. Army Corps of Engineers, 2001, Hydrologic Engineering Center, HEC-RAS, River Analysis System, version 3.1.3, May 2005.

U.S. Geological Survey, 1989, Guide for selecting Manning's roughness coefficients for natural channels and flood plains: U.S. Geological Survey Water-Supply Paper 2339, 38 p.

U.S. Geological Survey, 1998, Estimation of roughness coefficients for natural stream channels with vegetated banks: U.S. Geological Survey Water-Supply Paper 2441, 133 p.

Wagner, C.R., Mueller, D.S., Parola, A.C., Hagerty, D.J., and Benedict, S.T., 2006, Scour at contracted bridges: Transportation Research Board, National Cooperative Highway Research Program Document 83 (Project 24-14), 299 p. 
Prepared by the Pembroke Publishing Service Center.

For more information concerning the research in this report, contact:

Robert M. Lent, Director

U.S. Geological Survey

Maine Water Science Center

196 Whitten Road

Augusta, ME 04330

or visit our Web site at:

http://me.water.usgs.gov 
